\title{
Las FORTIFICACIONES AlMOHADES DE MADĪNAT IŠBİLIA EN EL CONTEXTO DE LA ARQUITECTURA MILITAR DE Al-Andalus (I)
}

DANiEl JimÉnez MaQueda Pedro PÉrez Quesada Consejería de Educación de la Junta de Andalucía

Recibido: 19/10/2015

Revisado: 07/01/2016
Aceptado: $30 / 03 / 2016$

Publicado: 30/06/2016
RESUMEN

El presente artículo tiene como objetivo el estudio de las fortificaciones con las que los almohades dotaron a madinat Išbīlia, entre los años 544/1150 y 618/1221-1222. Este estudio lo efectuamos desde una doble perspectiva: por una parte, los dispositivos que aquellos introdujeron en la muralla del siglo VI/XII; por otra, los numerosos recintos con los que ampliaron el primitivo Alcázar. En ambos casos, los relacionamos con la arquitectura militar de al-Andalus.

Palabras Clave

madīnat išbīlia; fortificaciones; almohades; alcázar.
ABSTRACT

This article aims to study the fortifications with which the Almohads endowed madinat Išbillia, between 544/1150 and 618/1221-1222. We make this study from two perspectives: on one hand, the devices placed in the wall of the $6^{\text {th }} / 12^{\text {th }}$ century; on the other, the many enclosures with which they expanded the original Alcázar. In both cases, we relate it to the military architecture of al-Andalus.

\section{KEYWORDS}

madīnat išbīlia; fortifications; almohads; alcázar

maqueda@hotmail.es

pedro@geasconsultores.com 
"Et es la meior çercada que ninguna otra allen mar ni aquen mar que fallada nin vista podiese ser, que tan llana estodiese; et los muros della son altos sobeiamiente et fuertes et muy anchos; torres altas et bien departidas, grandes et fechas a muy grant lauor; por muy bien çercada ternien otra villa de la su baruacana tan solamiente"

(Primera Crónica General de España).

\section{INTRODUCCIÓN}

Son varias las publicaciones que, en los últimos veinte años, hemos dedicado a defender la hipótesis de que el último recinto amurallado de madinat Išbìlia consta de dos fases ${ }^{1}$. La primera de ellas sería erigida entre los años 519/1125-1126 y 528/11331134, en tiempos del emir almorávide 'Alī ibn Yūsuf $^{2}$ (Jiménez Maqueda, 1996a; 1996b; 1998a; 1998b; 1998c; 1999a, 213-215; 1999b, 151-152; 2007, 167 y 170; Jiménez Maqueda y Pérez Quesada, 2012; 2015).

Sin embargo, no es nuestra intención insistir en los argumentos que nos han permitido sostener dicha cronología para la fase inicial ${ }^{3}$. Por el contrario,

1 Este artículo no se enmarca en ningún proyecto de investigación ni ha recibido ayuda financiera alguna por parte de ninguna institución pública o privada. Es por ello que resulta especialmente oportuno mostrar nuestro profundo agradecimiento a aquellos que han tenido la amabilidad de proporcionarnos su ayuda, como Miguel Ángel Tabales, del Departamento de Construcciones Arquitectónicas II de la Escuela Universitaria de Arquitectura Técnica de la Universidad de Sevilla, José Manuel Rodríguez, de la Delegación Provincial en Sevilla de la Consejería de Cultura de la Junta de Andalucía, Oscar Ramírez, del Servicio de Planeamiento de la Gerencia Municipal de Urbanismo del Ayuntamiento de Sevilla, Álvaro Jiménez, Enrique Domínguez, Mark Hunt, Francisca Gamarra, Florentino Pozo y Samuel Márquez.

2 Hemos defendido que la erección de la primitiva fase del recinto sevillano se produjo en un periodo de tiempo comprendido entre el año 519/1125-1126 y el 528/1133-1134, si bien hay autores que han sostenido como fecha de inicio de la misma el año 512/1118 (Valencia, 1988, 158-159). Ambas fechas permiten situar la obra defensiva en su adecuado contexto estratégico, en la medida en que la agresividad feudal obligó al Estado almorávide primero y a las autoridades locales después a dotar a Išbīlia de un nuevo recinto. Su análisis tipológico pone de manifiesto que su primitivo aspecto sería muy semejante a su contemporáneo de Marrakech, erigido por orden del emir 'Alī ibn Yūsuf en 520/1126. Es decir simple y bajo, sin decoración alguna y que se caracterizaría por torres con terraza a la altura del adarve y la ausencia de corachas, antemuro y torres poligonales (Jiménez Maqueda y Pérez Quesada, 2012; 2015).

3 En la defensa de una autoría almorávide para la pri- en esta ocasión nuestro propósito es el de estudiar las fortificaciones con las que los Unitarios dotaron a madinat Išbīlia entre los años 544/1150 y 618/1221-1222.

\section{LAS FORTIFICACIONES ALMOHADES DE MADINNAT} IŠBIILIA...

Entre los años 544/1150 y 618/1221-1222 los almohades sometieron a madīnat Išbīlia a un intenso programa de fortificación, consistente en recrecer y dotar a su recinto amurallado de sus característicos dispositivos poliorcéticos. Asimismo, procedieron a erigir una serie de recintos en el extremo meridional de la medina, los cuales ampliaron la superficie del primitivo alcázar 'abbādí de forma sustancial (figura 1) ${ }^{4}$.

La primera noticia que disponemos acerca de las fortificaciones almohades de Išbīlia la proporciona Ibn 'Idārī, quien narra en el Bayān al-Mugrib cómo, tras sofocar una revuelta de la ciudad a los pocos meses de su conquista en el año 541/1147, las autoridades almohades procedieron, en el 544/1150, a la construcción de “(...) «una alcazaba en Sevilla para que a ella se trasladaran los Almohades residentes en [el barrio del Cementerio] al-Ŷabbāna, por las quejas de la gente contra el daño que les causaban; decidido lo cual, determinaron un lugar -el mismo en el que se halla-, sacando a sus habitantes de sus casas (...)" (Viguera, 1998, 19-20; 1999, 20). Con ella se podrían identificar los lienzos documentados tanto en el Patio de las Doncellas (Tabales, 2003a; 2005a) como en el del Príncipe del Alcázar (Tabales, 2003b) $)^{5}$. Para ambos su excavador defiende, en

mera fase del recinto sevillano coincidimos, entre otros, con Alfonso Jiménez (Jiménez Martin, 1981, 16-17; 2000, 47 ss.; 2007a, 27 ss.), Rafael Valencia (Valencia, 1988, 156 ss.) o Enrique Domínguez (Domínguez, 2003, 295 ss.; 2014, 246250). Por el contrario, entre los más fervientes defensores de una paternidad almohade se encuentra Magdalena Valor, profesora del Departamento de Historia Medieval de la Facultad de Geografía e Historia de la Universidad de Sevilla (Valor, 1991; 1995a; 2002a, 48; 2002b; 2004, 147 ss.; 2008a, 25 ss.; 2008b, 147; 2009, 193 ss.; 2014, 252-253; Valor y Ramírez, 1999; 2000; Ramírez y Valor, 1999; Valor y Tabales, 2002; 2005, 196 ss.).

4 La publicación más reciente del director de sus intervenciones arqueológicas fecha el primitivo recinto del Alcázar en el siglo V/XI, descartando, por tanto, su identificación con el Dār al-Imāra emiral (Tabales, 2010a, 105 ss.).

5 Ambos forman parte del recinto del Alcázar al que el Dr. Tabales denomina Recinto III. Identificado por Alfonso Jiménez, ahora sabemos que erróneamente, con el Qars al-Mubārak 'abbādí (Jiménez Martín, 1981, 16), la primera 


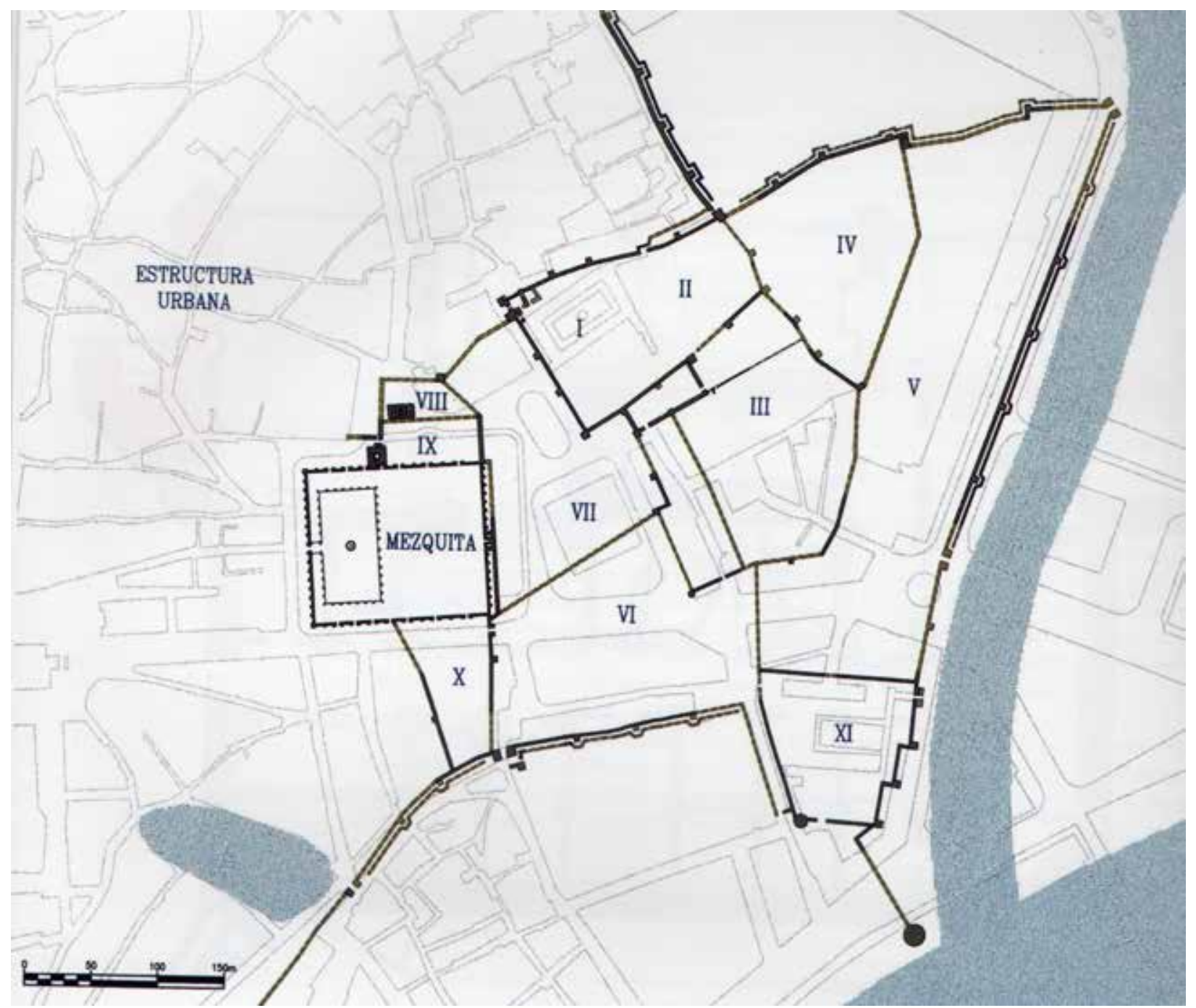

Figura 1. Recintos del Alcázar de madīnat Išbīlia en época almohade según Tabales Rodríguez (2010).

virtud del registro cerámico presente en sus respectivas zanjas de cimentación, una cronología de las décadas centrales del siglo VI/XII (figura 2). Se

propuesta para identificarlo con la alcazaba del año 544/1150 corresponde a la Dra. Valor (Valor, 2008a, 68). Quedaría delimitado, al norte, por el denominado muro de Santo Tomás, que conectaba el lado de Poniente del primitivo recinto del Alcázar con la Torre de Abdelaziz, desde donde giraba hacia el sur mediante un lienzo en el que se abriría el Arquillo de la Plata, cuyo actual aspecto es de indudable factura cristiana (Fernández, 1980, 77; Valor, 1991, 103; 2008a, 71; Jiménez Martín, 2000, 52). Por último, su flanco meridional, visible en la calle San Gregorio, enlazaría con la torre sudoccidental del Recinto II en la nomenclatura del Dr. Tabales, configurando así un espacio aproximadamente trapezoidal (figura 2) (Valor, 1991, 94 ss.; Tabales, 2001a, 22 ss.; 2002d, 268269; 2010a, 182 ss.). trataría así de la fortificación más antigua erigida por los Unitarios en al-Andalus, anterior incluso a las que se levantaron en Gibraltar, a lo largo de $555 / 1160$, por orden del califa 'Abd al-Mu'min (Ibn Sāhib al-Salāt, 1969, 21-23; Torres Balbás, 1942a; Sáez y Torremocha, 2001; Sáez, 2007).

Por su parte, Ibn Sāhib al-Salāt afirma en el Mann bi-l-Imāma que, en el año 564/1168-1169, Abū Ya'qūb ordenó la reconstrucción de "sus murallas por el lado del río, a su costa, después que las derribó la inundación grande, que salió por sus costados y por su región el año 564. Las construyó de piedra y cal, desde ras de tierra hasta la altura que tienen hoy, por la mano de sus encargados más fieles" (Ibn Sāhib al-Salāt, 1969, 64). Sin embargo, compartimos con Enrique Domínguez las dudas re- 


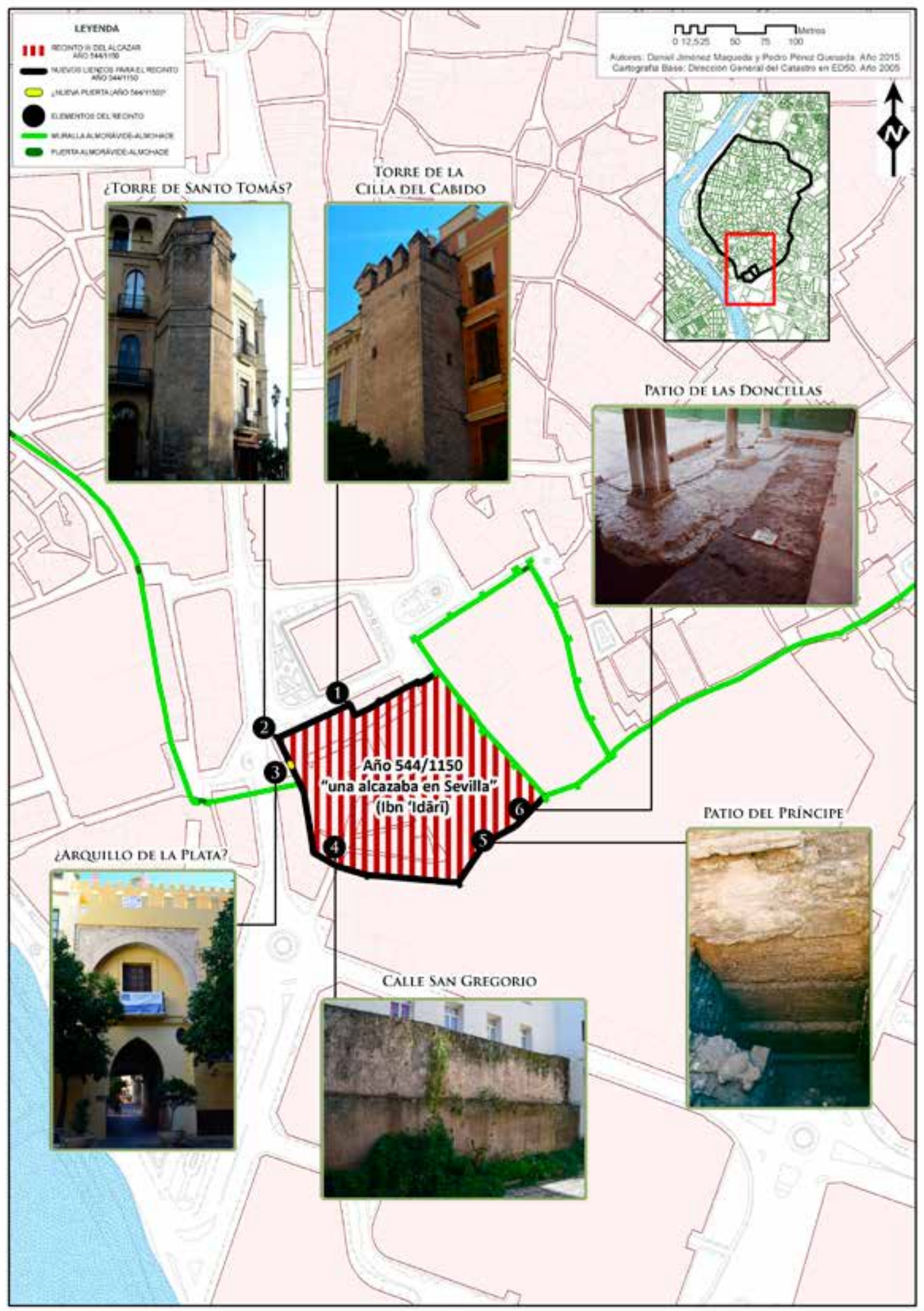

Figura 2. Hipótesis sobre el emplazamiento del recinto de la alcazaba del año 544/1150. 
lativas a que la extensión de los lienzos derruidos abarcase todo el frente occidental, tal y como han defendido otros investigadores (Salem, 1979-1980, 177; Valencia, 1988, 160; Valor, 2002a, 47). Con todo, en relación a este punto resultan de interés los resultados proporcionados por la intervención arqueológica llevada a cabo en la Puerta Real por el Servicio de Planeamiento de la Gerencia Municipal de Urbanismo (lámina 1). En ella, a pesar de no haber alcanzado los niveles fundacionales de la muralla, el lienzo documentado se vincula con el pasaje anterior (Ramírez y Vargas, 1995, 87).

Es el mismo Ibn Sāhib quien nos informa de cómo Abū Ya'qūb "Se instaló en Sevilla el año 566 [14 septiembre 1170 a 3 septiembre 1171] (...) Labró la alcazaba interior y la alcazaba exterior en las afueras de la puerta de al-Kuhl (...)" (Ibn Sāhib al-Salāt, 1969, 65) (figuras 3 y 4). En cuanto a la identificación de ambos recintos defensivos, sus nombres son expresivos, de modo que la primera se construiría al interior de la cerca del siglo VI/XII, mientras que la segunda lo sería al exterior de la misma "(...) en las afueras de la puerta de al-Kuhl (...)". Por lo tanto, resulta evidente que para ello es determinante la localización de este elemento de la topografía urbana de madīnat Išbīlia. Al respecto, aunque la historiografía sevillana ha propuesto los más diversos emplazamientos para el mencionado acceso $^{6}$, en 1981 Alfonso Jiménez propuso identificarla con la que "debía estar situada a la entrada de J. Hazaña, entre el Coliseo y la Casa de la Moneda” (Jiménez Martín, 1981, 17). En esta línea, las excavaciones efectuadas, bajo la dirección de Gregorio Mora, en la fachada de la Real Casa de la Moneda han permitido documentar sendas torres de planta cuadrangular, dispuestas en oblicuo, que conforman un vano de 3'30 m de anchura y están erigidas con tapias, que presentan una elevada proporción de cal y un color exterior grisáceo (Mora, 2013, capítulo 2,80). Además, el nombre de al-Kuhl alude al sulfuro de plomo con el que los alfares islámicos vidriaban sus producciones, varios de los cuales se han documentado en el entorno del Alcázar y la Puerta de Jerez (figura 5) ${ }^{7}$.

6 También se ha propuesto su identificación con el Postigo del Carbón (González, 1951, tomo I, 473), la Puerta de Goles (Bosch, 1984, 313) o el Arquillo de la Plata (Valor, 2008a, 71).

7 En el corte I de la Acera de la Catedral se documentó un pequeño horno, acompañado por sendos muros en ángulo y asociado a una torta de material cerámico, para los

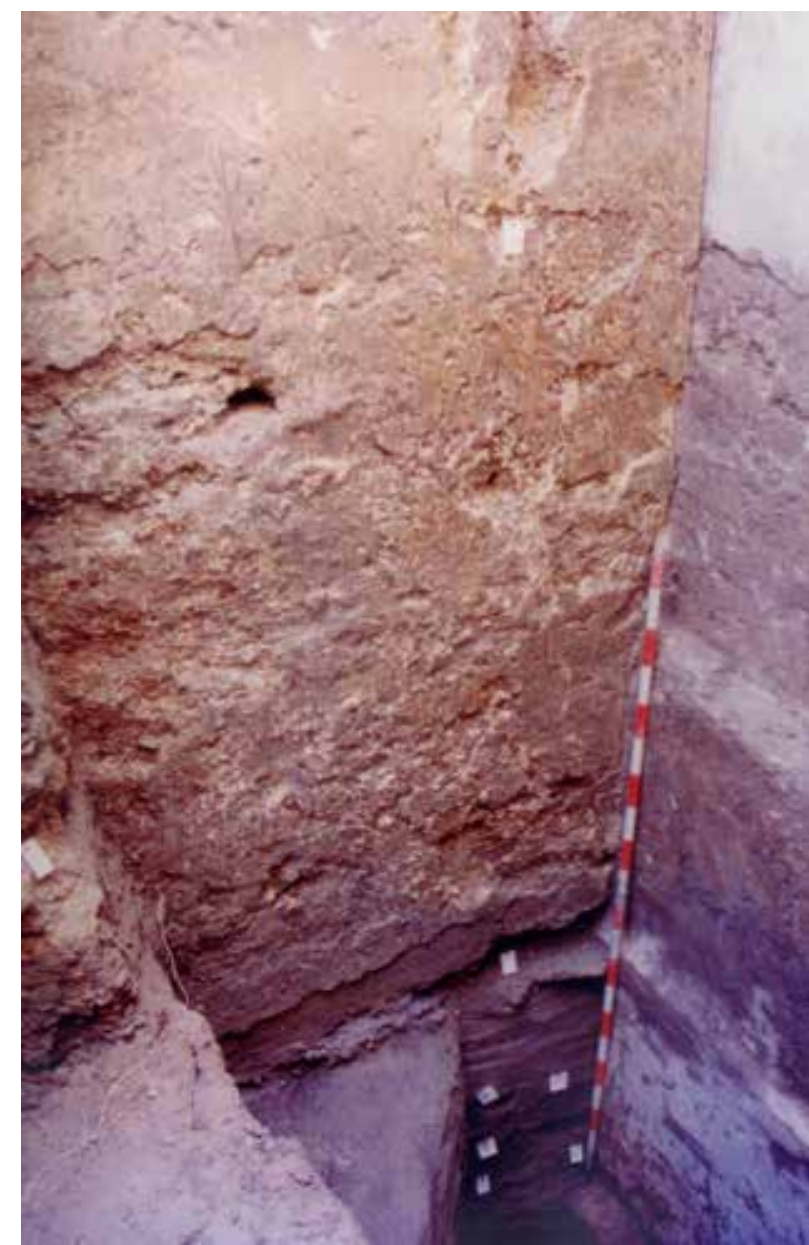

Lámina 1. Intervención arqueológica efectuada en la Puerta Real (fotografía cortesía del Servicio de Planeamiento de la Gerencia Municipal de Urbanismo del Ayuntamiento de Sevilla).

que sus excavadores sostienen una cronología de los siglos X-XI (Tabales et alii, 2001, 400; 2002, 136). En el Patio de las Doncellas del Alcázar se excavaron los restos de hasta tres hornos cerámicos superpuestos, con una cronología que iría desde finales del siglo X al XI (Tabales, 2003a, 11; 2005a, 55-56; 2005b, 9-12; 2010b, 1087-1088), mientras que en la galería de los Baños de Doña María de Padilla del Alcázar se hizo lo propio con un horno al que sus excavadores asignan una cronología del siglo XI (Tabales, 2003b, 59-60). En la Plaza de la Puerta de Jerez se han documentado cuatro hornos cerámicos datados entre el siglo XI y el tercer cuarto del XII, si bien la circunstancia de que no fueran excavados con metodología arqueológica impide mayores precisiones al respecto (Martínez y Pozo, 2007). Por último, en la Avenida de Roma se documentaron un horno de producción cerámica, así como restos de otros dos de tamaño mucho menor, para los que sus excavadores sostienen una cronología anterior al dominio almorávide (Gamarra y Camiña, 2006, 494 y 498). A los resultados de estas intervenciones, habría 


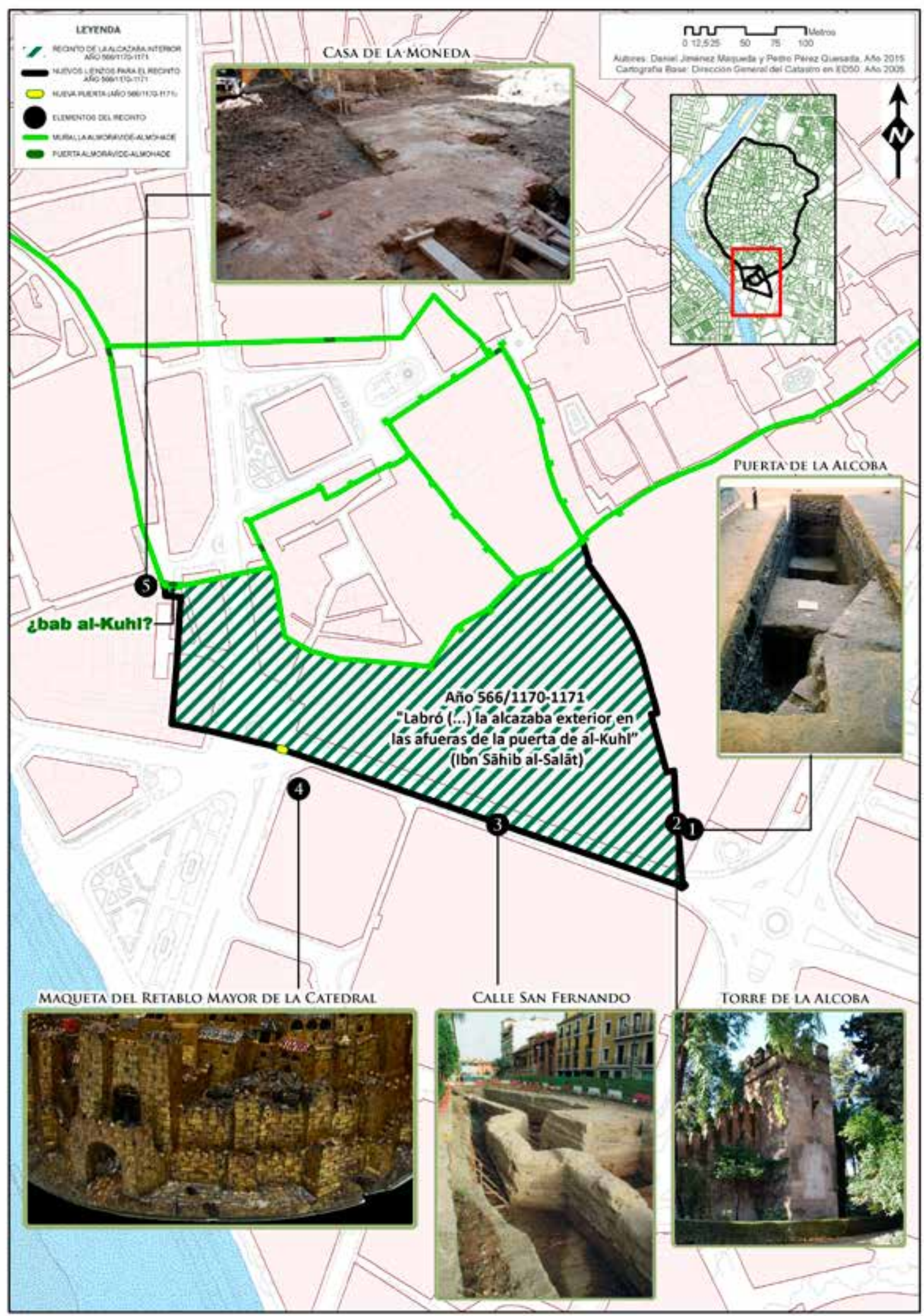

Figura 3. Hipótesis sobre el emplazamiento del recinto de la alcazaba exterior del año 566/1170-1171 basado en Jiménez Martín (1981). 


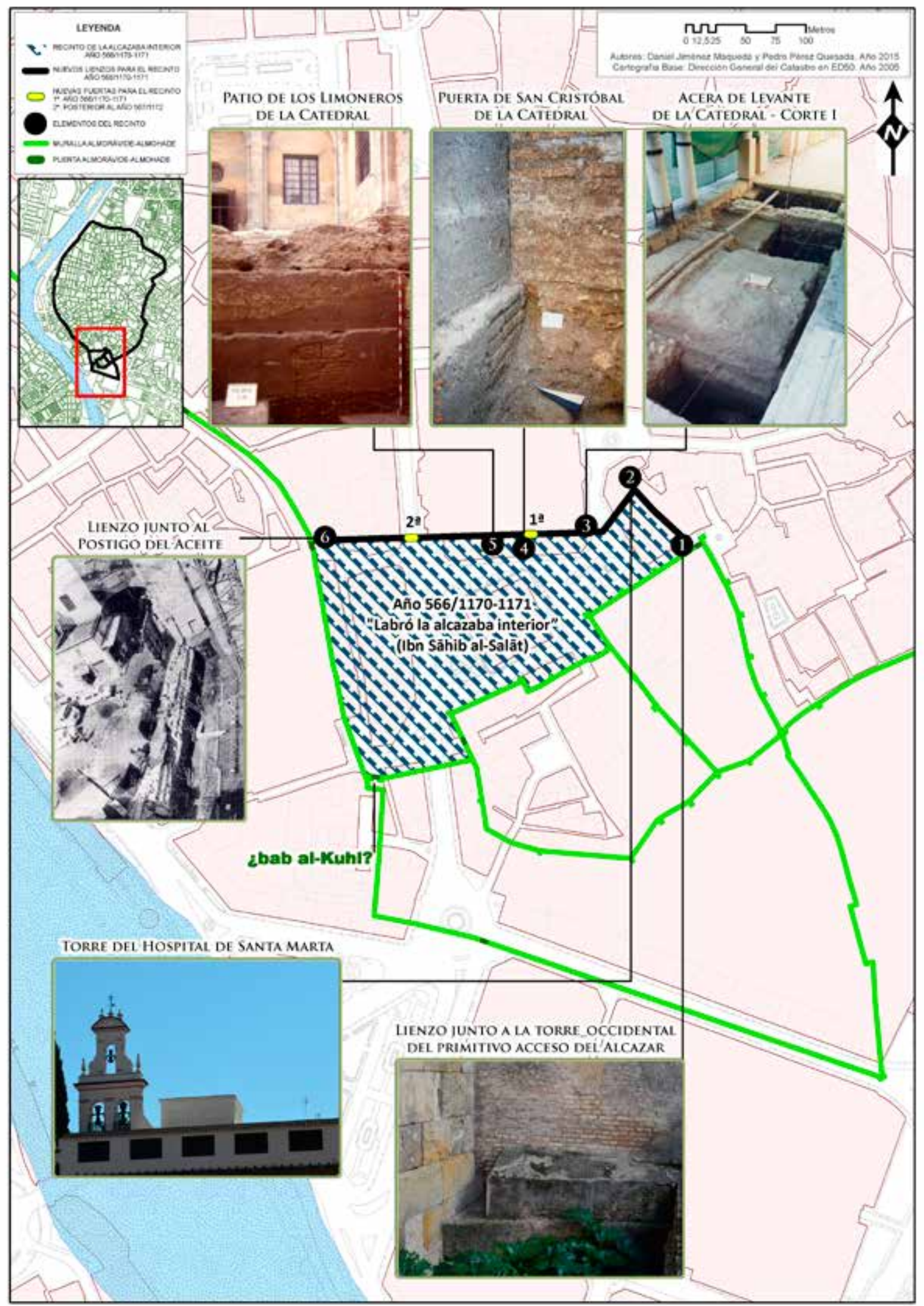

Figura 4. Hipótesis sobre el emplazamiento del recinto de la alcazaba interior del año 566/1170-1171 basado en Jiménez Martín (1981). 


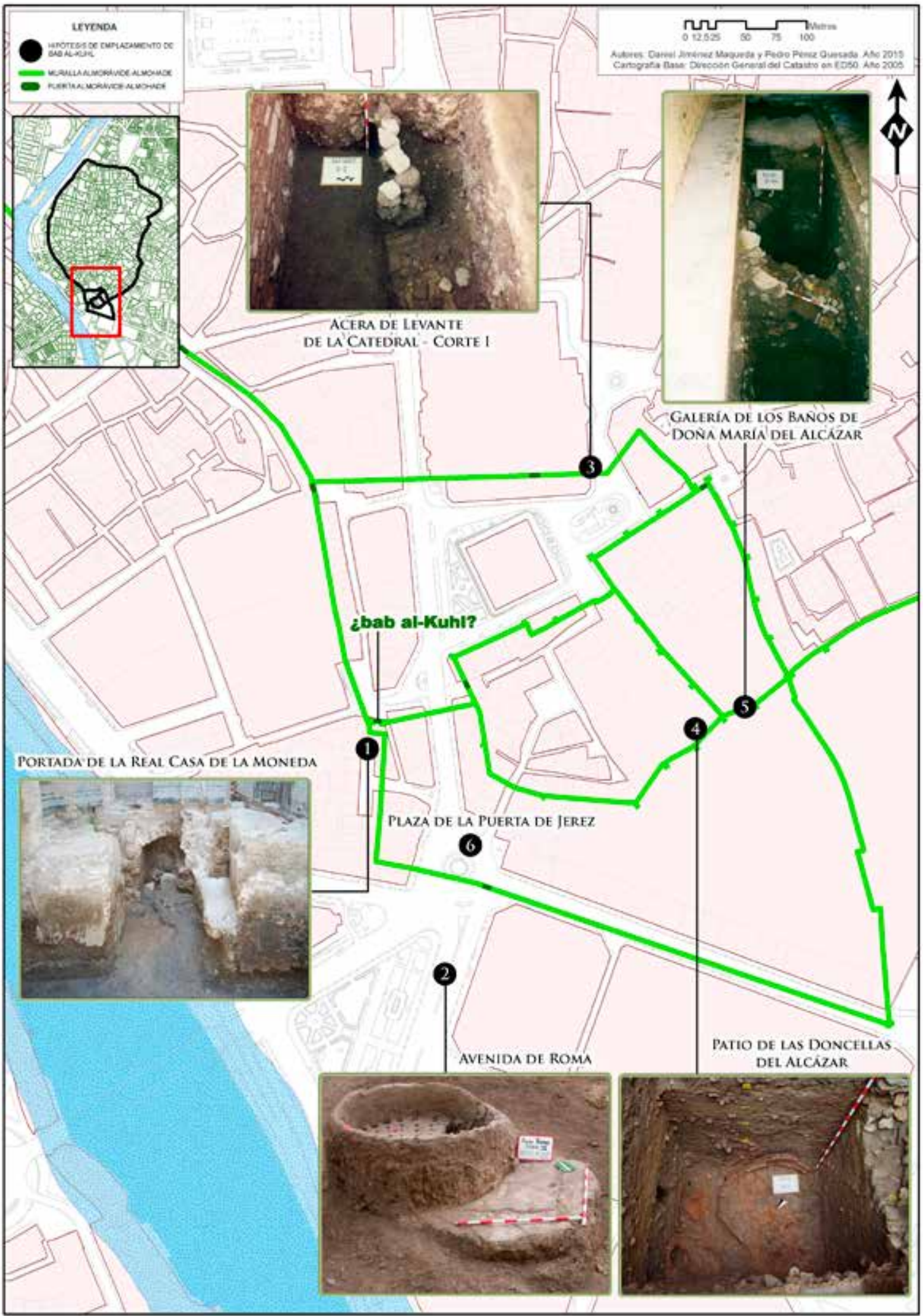

Figura 5. Hipótesis sobre el emplazamiento de la $b \bar{a} b$ al-Kuhl basado en Jiménez Martín (1981). 


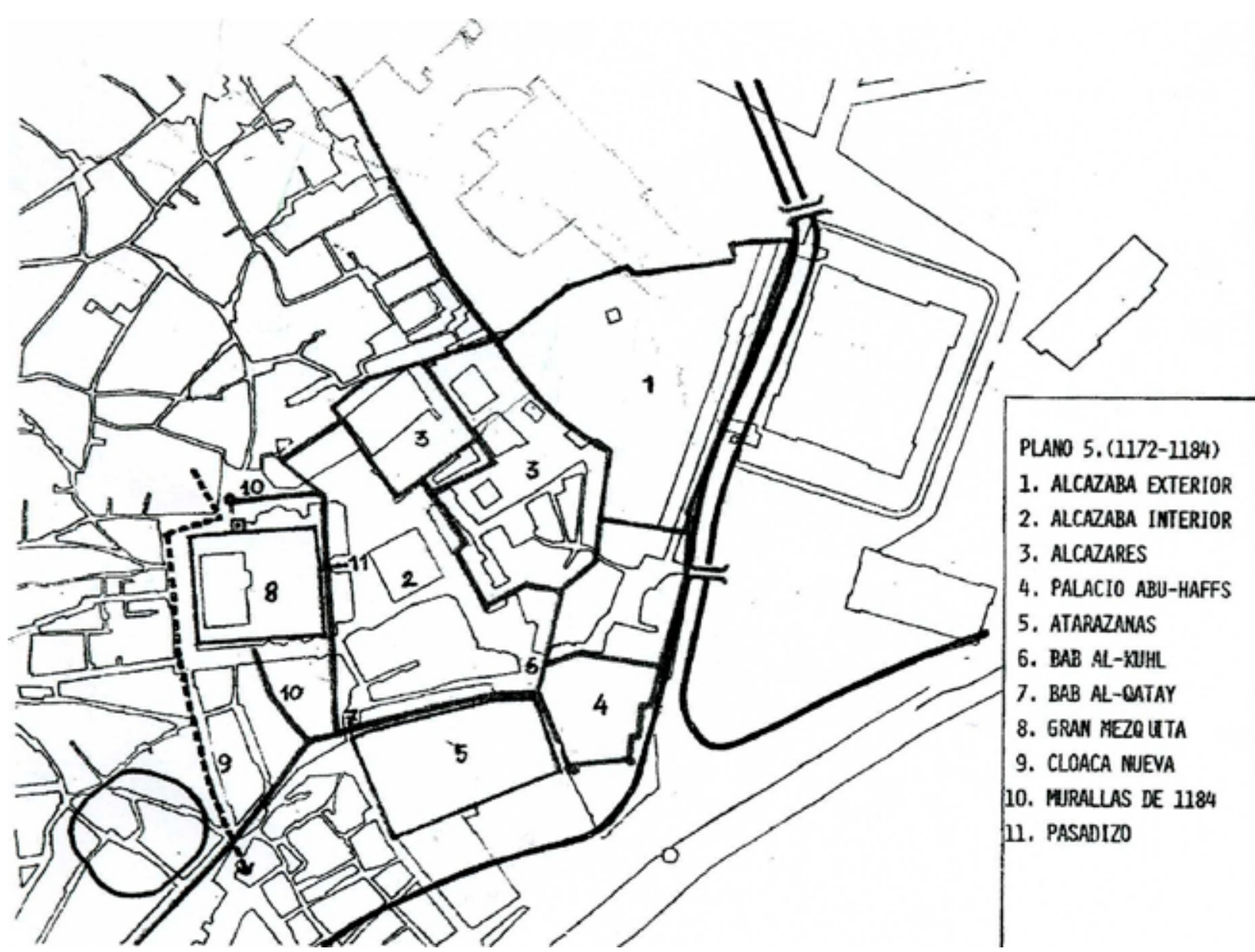

Figura 6. Hipótesis sobre el emplazamiento de los recintos del Alcázar (1172-1184) según Jiménez Martín (1981).

Fue el mismo Alfonso Jiménez quien, en 1981, propuso identificar la alcazaba exterior con el recinto que, en el siglo XV, se denominaba "Huerta de la Alcoba", mientras que la alcazaba interior se

que añadir los desechos de alfar a los que alude Carriazo en la inspección de la zanja practicada en 1960 para el alcantarillado entre la Avenida de la Constitución y la Plaza Nueva. En la actual Plaza de la Puerta de Jerez hace mención "a una cantidad prodigiosa de cerámica vidriada de los siglos X, XI y XII" (Carriazo, 1974-1975, 95-96).

8 Este recinto quedaba delimitado mediante un lienzo que partía de la Torre del Agua en dirección sur, excavado por el Dr. Tabales en 1999 en los sondeos SE-IV. Galería del Grutesco (Tabales, 2002a, 227-228; 2002c, 208 ss.) y SE-V. Puerta de la Alcoba del Alcázar (Tabales, 2002a, 228-230; 2002c, 218 ss.), hasta el punto en el que en el siglo XVIII se abrió la Puerta Nueva o de San Fernando (Suárez, 1989). Desde aquí, giraba hacia Poniente a lo largo de la calle San Fernando, con el arroyo Tagarete como foso, y en la que gran parte de este lienzo meridional fue excavado, bajo la dirección de Mark Hunt, en el transcurso de las obras de la línea 1 del Metro, a lo largo del año 2004 (Hunt et alii, emplazaría entre el Alcázar y la actual Catedral, en lo que, en el siglo VI/XII, se conocía como la "Explanada de Ibn Jaldūn” (figura 6) ${ }^{9}$. Asimismo, se ha 2010) (figura 3). En él se abriría un acceso, al que desde 1402 se conocerá como Puerta de Jerez (Collantes de Terán, 1972, 49-50, documento 107), y cuya primitiva disposición figura en la maqueta de la ciudad vista desde el sur del Retablo Mayor de la Catedral (Sancho, 1975, 1; Cabra y Santiago, 1988, 4; Morón, 1998). La documentación, en el sondeo SEIV del Alcázar, de un lienzo de grava, abundante cal y arcillas anaranjadas, con orientación este-oeste y que entesta en ángulo recto con la muralla del Grutesco, ha permitido al Dr. Tabales sostener que el mencionado lienzo dividiría la antigua Huerta de la Alcoba en dos recintos diferentes (Tabales, 2002a, 227-228; 2002c, 215).

9 Este recinto quedaría delimitado, hacia el norte, por un lienzo que discurría, desde el Postigo del Aceite, paralelo a mediodía de la mezquita aljama, excavado en el Patio de los Limoneros (Tabales y Jiménez, 2001; 2002), en la Puerta de la San Cristóbal (Rodríguez et alii, 1994; Rodríguez y Ramírez, 1997) y en el corte I de la Acera de Levante de la Catedral (Tabales et alii, 2001; 2002). Por su parte, hacia 
sugerido que la puerta documentada bajo la fachada de la Real Casa de la Moneda perdería su carácter urbano y se limitaría a facilitar el tránsito entre ambas alcazabas. Para ello se erigió un muro construido con tapias de color anaranjado, que describe ante la puerta un recodo, al configurar un espacio a cielo abierto de cinco metros de longitud por trece de anchura (Mora, 2013, capítulo 4, 117 y 124).

Sin embargo, aparte de la Dra. Valor, quien en su tesis doctoral propuso una localización alternativa para ambas alcazabas (Valor, 1991, 258 ss.), ha sido el propio Alfonso Jiménez quien ha matizado su primitiva propuesta en sus más recientes publicaciones. De este modo, la alcazaba interior parece haber desaparecido, en la medida en que, como veremos más adelante, su lienzo septentrional se atribuye ahora a las obras de Abū Yūsūf, tras la muerte de su padre en 580/1184 (Jiménez Martín, 2000, figura 7; 2007b, figura 3).

Por nuestra parte, la afirmación de Ibn Sāhib de que para el comienzo de las obras de la aljama almohade, en el mes de ramadān del año 567/27 de abril a 26 de mayo de 1172, “(...) se demolieron para ello

el sur lo estaría por los lienzos septentrionales de la primera alcazaba almohade y el primitivo recinto del Alcázar, es decir los recintos I y III en la nomenclatura del Dr. Tabales; al oeste por el tramo de la cerca urbana comprendida entre los postigos del Aceite y del Carbón; y al este las mayores dificultades estriban en determinar cómo se efectuaba la conexión entre el lienzo que partía junto a la torre occidental de la puerta de la calle Joaquín Romero Murube y el que procedía del corte I de la Acera de Levante de la Catedral, así como el papel que desempeñaba la torre que todavía se conserva dentro del Hospital de Santa Marta (figura 4).

En dicho recinto se abría la Puerta de San Miguel, de la que existen sendas representaciones (Serrera et alii, 1989, 216 y 275) y numerosas descripciones (Hernández, 1993) y cuyos restos se localizaron en el número 23 de la Avenida de la Constitución (Carriazo, 1964-1965; Collantes de Terán, 1977, 112) y en una zanja practicada en 1990 como consecuencia de las obras de ampliación de la Compañía Telefónica (Rodríguez, 1993). En ambos casos, el material constructivo eran los sillares, aunque en esta última, a 550 $\mathrm{m}$ al norte, se documentó una estructura de argamasa con abundante cal, sin que fuese posible detectar nexo alguno entre la citada estructura y los sillares.

En función de la orientación de las viviendas almohades posteriores a la erección de la aljama, el Dr. Tabales ha sugerido la existencia de una orientación previa dominante. Consistiría esta en un lienzo que conectaba la Puerta de San Miguel con el lienzo del Alcázar que iba desde la Puerta del León a la Torre de Abdelaziz, tal vez a la altura de la torre de la Cilla del Cabildo (Tabales y Jiménez, 2001, 437 y 440; 2002, 235, 240, 241, 247 y 255). las casas a la entrada de la alcazaba (...)" (Ibn Sāhib al-Salāt, 1969, 195) incide en la localización de la alcazaba interior en la "Explanada de Ibn Jaldūn”. De este modo, son varias las intervenciones arqueológicas efectuadas en el solar de la mezquita aljama en las que se han documentado diversos restos de carácter doméstico, correspondientes, sin duda, a las casas mencionadas por al-Salāt ${ }^{10}$. Por otra parte, el inicio de las obras de la mezquita obligaría a desplazar hacia occidente el acceso de la alcazaba interior por razones evidentes, de manera que la puerta de San Miguel sería posterior a la citada alcazaba, pero contemporánea de la aljama almohade ${ }^{11}$.

Ibn Abī Zar' da cuenta en el Rawd al-qirtās de cómo, en el año 567/1171-1172, Abū Ya'qūb procedió a erigir “(...) el muro de la puerta de Ŷahwar" (Ibn Abī Zar', 1964, 417). Este pasaje ha servido a Magdalena Valor para sostener que fue entonces cuando tuvo lugar la construcción del lienzo que conectaba la Puerta de la Carne y la Torre del Agua del Alcázar (Valor, 1991, 215 y 217; 1995a, 54; 2002a, 47; Valor y Tabales, 2005, 197). Sin embargo, dicha hipótesis parte del erróneo presupuesto de identificar la Puerta

10 En el pilar 4C de la Catedral se documentaron una atarjea y una cimentación de gran anchura, que podrían pertenecer a un contexto doméstico del siglo XI (Jiménez Sancho, 2002a; 2002c, 299), así como los restos de una calle, bajo la que discurría una atarjea, y los de sendas casas situadas a ambos lados de la misma, erigidas en la primera mitad del siglo XII (Jiménez Sancho, 2002a; 2002c, 299-303). En el Patio de los Naranjos de la Catedral el muro de una alberca, perteneciente a un edificio de carácter doméstico y una cronología de los siglos X-XI (Jiménez Sancho, 2002e, 364; 2003) y los restos de una calle, bajo cuyo piso discurrían sendas canalizaciones de atanores, y los de una casa, erigida a principios del siglo XII (Jiménez Sancho, 2002e, 365-366; 2003). En las gradas de la Puerta del Perdón de la Catedral restos que consisten en una alcantarilla de ladrillo sobre la que discurría una calle, con una cronología de la primera mitad del siglo XII (Jiménez Sancho, 2002b; 2002d, 340 y 342).

11 Según las excavaciones del Dr. Tabales en el Pabellón de Oficinas de la Catedral, la erección de la mezquita aljama almohade precisó de una ingente labor de adecuación de la topografía de la zona. Así se documentó una plataforma de nivelación de argamasa muy compacta de $3 \mathrm{~m}$ de espesor, cuya superficie se situaba en la cota de $7 \mathrm{~m}$. Su finalidad sería la de crear una base estable para la mezquita y sobre ella se dispuso un relleno artificial de entre tres y un metro de espesor. Asimismo, en el extremo meridional de la mencionada zapata de nivelación se documentaron los restos de un talud encalado, compuesto por rellenos artificiales, que suavizaba el desnivel entre la cota de la superficie de plataforma y la del exterior (Tabales y Jiménez, 2001; 2002). 
de la Carne con la $b \bar{a} b \hat{Y} a h w a r$, denominación que correspondería con la que se localizaba al pie de la mencionada torre ${ }^{12}$.

En este orden de cosas, la $b \bar{a} b \hat{Y} a h w a r$ formaba parte de un dispositivo que permitía a los califas almohades acceder desde los recintos del Alcázar a la Buhayra, sin tener que cruzar la ciudad y por el camino más corto (figura 7). Dicho dispositivo, constaba de la puerta en recodo que, todavía hoy, permite el tránsito desde el Patio de Banderas del Alcázar hasta la calle Judería; un muro, al que podría hacer alusión Ibn Abī Zar', cuya existencia es evidente en un plano de los Reales Alcázares del siglo XVII, y unía esa puerta con la $b \bar{a} b \hat{Y} a h w a r$, configurando así un pasadizo protegido entre ambas, es decir un sābāt al que sólo tendrían acceso el califa y su séquito; $y$, por último, una puerta en recodo al pie de la Torre del Agua, la $b \bar{a} b \hat{Y} a h w a r$, tal y como figura en la maqueta del Retablo Mayor de la Catedral en el que se representa a la ciudad desde el sur (Sancho, 1975, 1; Cabra y Santiago, 1988, 4; Morón, 1998), excavada por Miguel Ángel Tabales en el sondeo SE-III. Puerta de Marchena del Alcázar en $1999^{13}$.

En esta línea, resulta del mayor interés la mencionada intervención arqueológica, puesto que en ella se habrían documentado sendas murallas superpuestas con la misma alineación, lo que, por el momento, constituye una circunstancia excepcional en el recinto sevillano (lámina 2). Para la primera el Dr. Tabales sostiene una cronología almorávide, mientras que a la segunda atribuye una datación "antes de 1172" en función del registro cerámico (Tabales, 2002a, 223 y 225; 2002c, 201).

No obstante, es Alfonso Jiménez quien ofrece la clave en su penetrante análisis de la lógica constructiva del alzado del tramo de muralla entre la Puerta

12 Hace años ofrecimos una relación de los argumentos para rechazar la identificación entre la Puerta de la Carne y la $b \bar{a} b \hat{Y} a h w a r$ a los que remitimos (Jiménez Maqueda, 1998b).

13 La apertura de la $b \bar{a} b \hat{Y} a h w a r$ fue acompañada por la erección ex novo del lienzo oriental de, al menos, el recinto II del Alcázar. Así lo ponen de manifiesto los resultados proporcionados por los sondeos SE-VIII. Patio del Chorrón y SE-IX. Patio de la Alcubilla del Alcázar. En el primero de ellos, se documentó un lienzo de tapial con cadenas de ladrillo (Tabales, 2003b, 62-63), mientras que, en el segundo, se hizo lo propio con uno de tapial con encadenado profundo de ladrillo a soga y tizón de un pie (Ibidem, 64-66). En ambos casos los lienzos almohades se superponen sobre sendos de cronología taifa. de la Carne y el Alcázar (Jiménez Martín, 2000, 50-51; 2007a, 28-29). Así, los merlones más antiguos están rotos por la cañería que conducía el agua desde los Caños de Carmona, fechada con exactitud el sábado 15 de $\hat{y} u m \bar{a} d a$ al-ajira del año 567/13 de febrero de 1172. En palabras del omnipresente Ibn Sāhib, Abū Ya'qūb “(...) mandó conducirla [el agua] y llevarla al interior de Sevilla, a los palacios, para bebida y comodidad de la gente con su más perfecta generosidad, con acabada ingeniería y disposición (...)" (Ibn Sāhib al-Salāt, 1969, 191). Esta circunstancia revela, de forma evidente, que la cañería no estaba prevista en el primitivo lienzo y que supuso una significativa modificación del mismo, pues obligó a recrecer el adarve y a repetir la merlatura de manera inmediata. Por su parte, las torres serían recrecidas algún tiempo después, ya que las cámaras

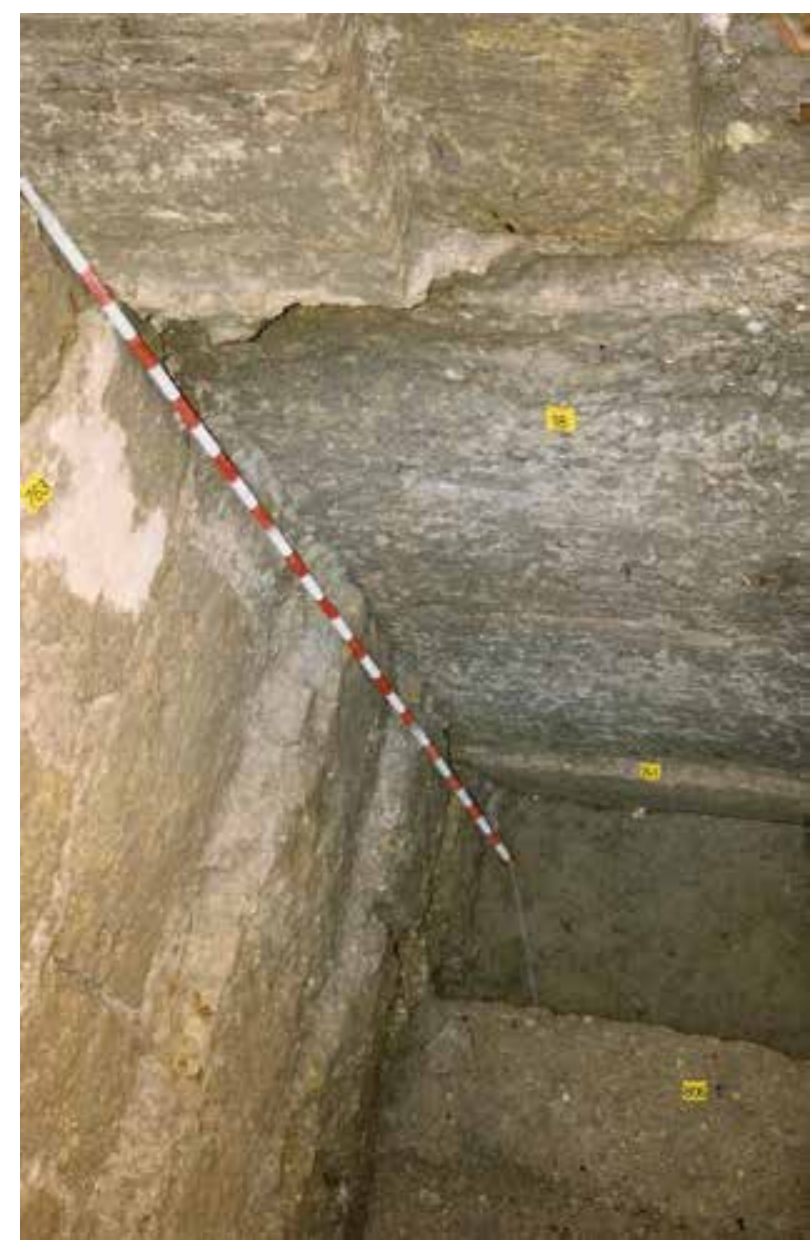

Lámina 2. Superposición de los lienzos amurallados UE 741 y UE 18, documentados en el sondeo SE.III en la Puerta de Marchena del Alcázar de Sevilla (fotografía cortesía de Miguel Ángel Tabales). 


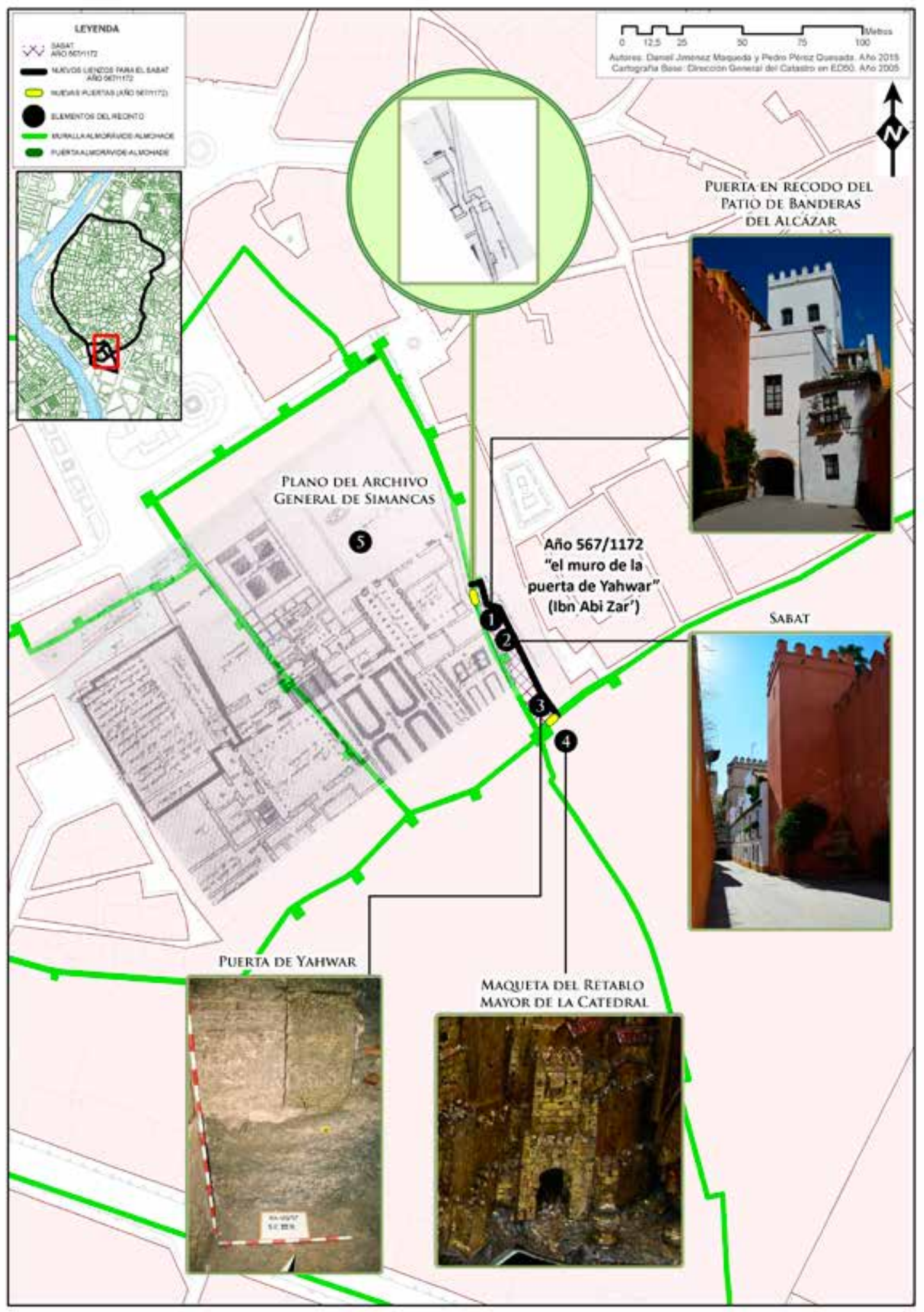

Figura 7. Hipótesis sobre el emplazamiento de la $b \bar{a} b$ Ŷahwar según Jiménez Maqueda (1998). 
de las mismas no tienen relación aparente con la cañería.

Por lo tanto, la muralla del Agua representa un elemento fundamental para reconstruir el proceso constructivo del último recinto amurallado de Sevilla, en cuanto que la conducción de atanores supone un elemento perfectamente fechado que permite distinguir dos fases (lámina 3). Para la primera de ellas Miguel Ángel Tabales sostiene una cronología almohade anterior a 1172, datación que resulta radicalmente incompatible con la hipótesis de Magdalena Valor de identificar la muralla del Agua con el muro de $\hat{Y} a h w a r$. La conducción de atanores, fechada por Ibn Sāhib al-Salāt $\hat{y} u m a \bar{a} d a$ al-ajira del año 567/febrero de 1172, invalidaría dicho muro apenas hubiera sido concluido a lo largo del año 567/1171-1172 o, rayando el absurdo, la conducción de atanores sería previa al propio muro. Supondría, tal y como ha señalado con sorna Alfonso Jiménez, que los atanores levitaran al carecer de soporte. Se trataría así de obras mutuamente excluyentes.

Es una vez más Ibn Sāhib al-Salāt quien da cuenta de cómo se tendió el Puente de Triana sobre las aguas del Guadalquivir, entre el 1 de muharrām/4 de septiembre y el 7 de safar del año 567/9 de octubre de 1171, cuando Abū Ya'qūb “(...) estuvo presente el día de su terminación, hasta que se amarró el pasadizo sobre el puente de barcas y se colocó sobre el río" (Ibn Sāhib al-Salāt, 1969, 186-187). El objeto de nuestro trabajo es determinar cuándo se erigió la fortificación, conocida como Castillo de San Jorge, para la defensa del mencionado puente, es decir si se trata de una fortificación contemporánea del mismo o si, por el contrario, es posterior.

En este sentido, las excavaciones llevadas a cabo bajo la dirección del Dr. Hunt a lo largo de 1998 y 1999 permitieron documentar un recinto de planta rectangular de ca. $60 \times 48 \mathrm{~m}$, cuyos ángulos coinci-

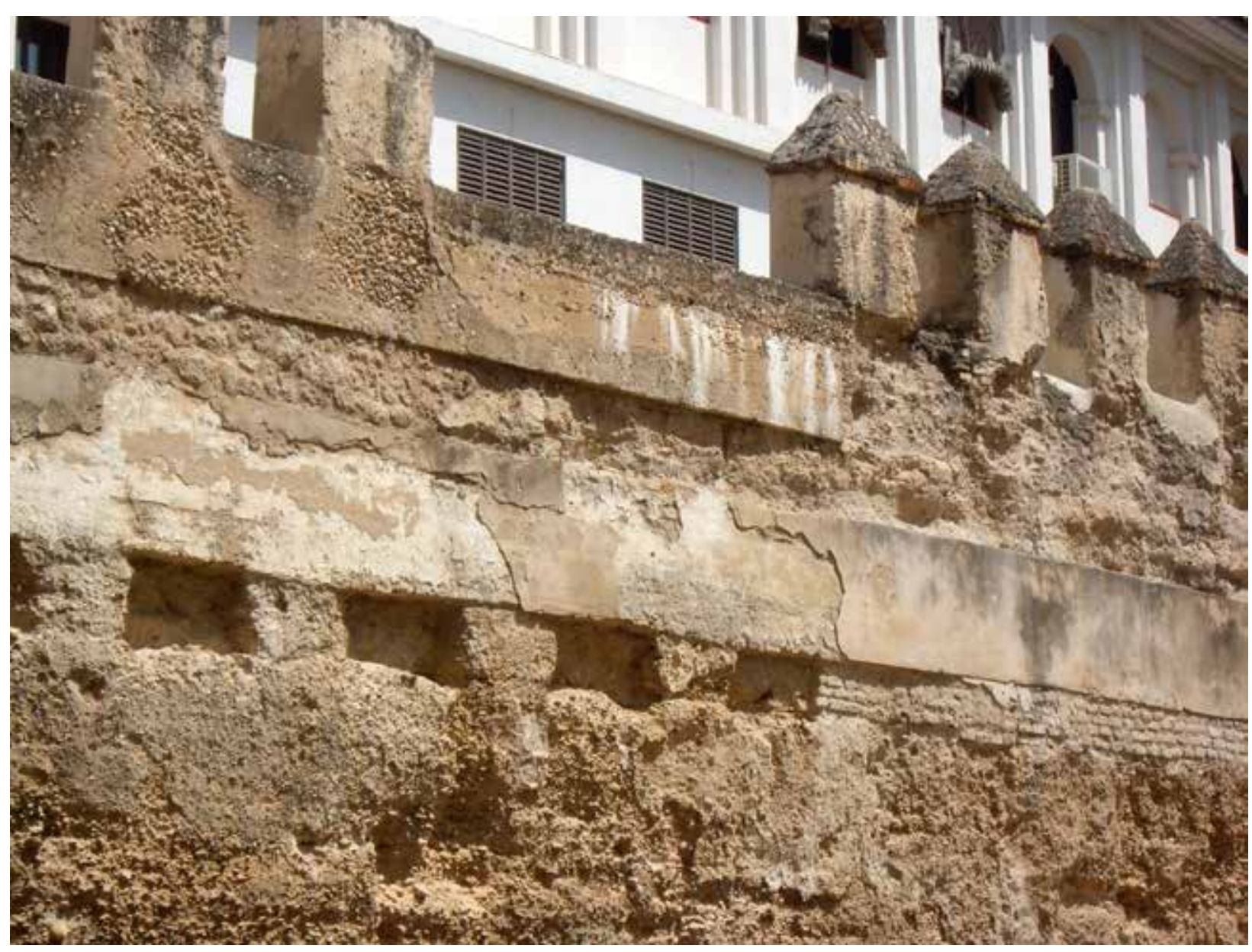

Lámina 3. Superposición de las dos fases de la muralla del Lienzo del Agua y el conducto de los Caños intercalado, que rompe los merlones más antiguos (fotografía de Daniel Jiménez). 
dían con los puntos cardinales. Sus lienzos se erigieron mediante cajones de tabiya con una cimentación muy reducida y tan sólo se localizó una torre cuadrangular, adosada al lienzo en su parte inferior, mientras que en la superior ambos formaban una obra única (lámina 4). En cuanto a su fecha de construcción, sus excavadores sostienen que tendría lugar en un momento almohade muy tardío, probablemente la primera mitad del siglo VII/XIII, en función de los elementos arqueológicos recuperados en su fosa de cimentación, así como de los fragmentos cerámicos presentes en la propia obra (Hunt, 2001, 817-818). Por lo tanto, el puente de barcas y la fortificación que protegía su cabecera no serían contemporáneos, sino que esta última lo es de las mejoras introducidas en la cerca por los almohades en los años finales de su dominio de la ciudad.

Es de nuevo al-Salāt quien se hace eco de que el 13 de safar de 580/26 de mayo de 1184 el califa Abū Ya'qūb "(...) mandó a su gobernador Abū Dāwūd Yalūl b. Ŷaldāsan, que se ocupase durante su ausencia por la campaña, en construir una muralla fuerte en la alcazaba de Sevilla, que pasase desde el principio de su construcción por delante de la explanada de Ibn Jaldūn, dentro de Sevilla, y levantar el almi- nar de la mezquita, que estuviese en la unión de la muralla con la mezquita dicha (...). Empezó Abū Dāwūd por derribar casas y excavar los cimientos de la muralla delante de la explanada ya dicha y así continuó cerca de mes y medio, hasta que murió (...)" (Ibn Sāhib al-Salāt, 1969, 200). Tras la muerte de su padre ante los muros de Santarem, Abū Yūsūf, el nuevo califa, ordenó la detención de los trabajos a mediados de agosto de ese mismo año, cuando "(...) renunció a construir la muralla de la alcazaba (...)" (Ibidem, 201).

Constituía un lugar común en la historiografía sevillana, siguiendo una vez más a Alfonso Jiménez, el identificar las murallas a las que alude alSalāt tanto con la que partía de la cerca urbana, al norte del Postigo del Aceite, y de la que se conserva un lienzo en la Plaza del Cabildo, como con la que, desde el lienzo que cerraba la alcazaba interior por el norte, lo hacía en dirección a la medina hasta la altura de la cara oriental de la futura Giralda (figura 6) (Jiménez Martín, 1981, 18-19; 1995b, 158).

Sin embargo, la documentación, durante las obras de saneamiento desarrolladas delante de la Puerta del Perdón en 1999, de una cimentación de sillares ha permitido al propio Alfonso Jiménez formular

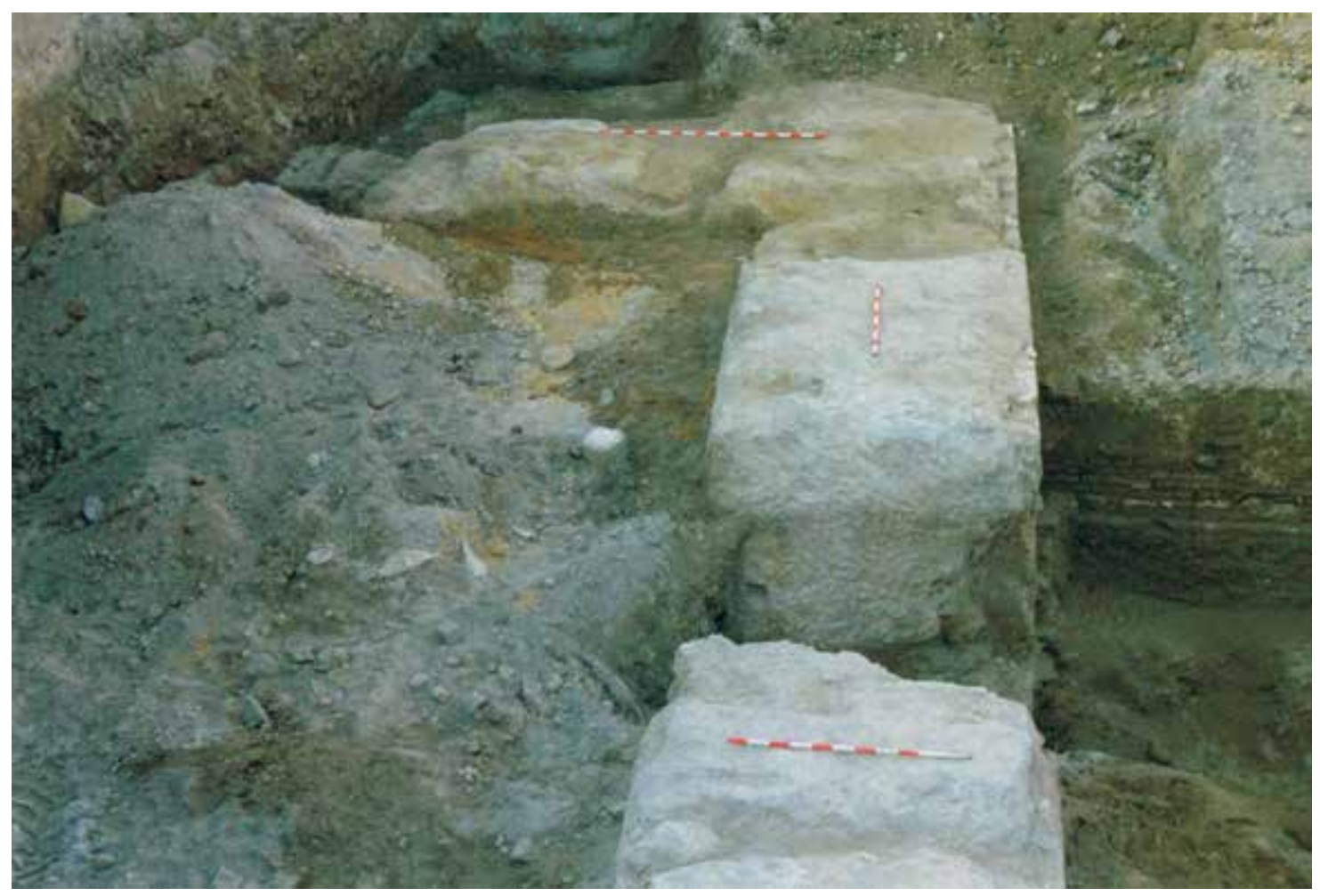

Lámina 4. Lienzo sur documentado en el Castillo de San Jorge de Triana (fotografía cortesía de Mark Hunt). 


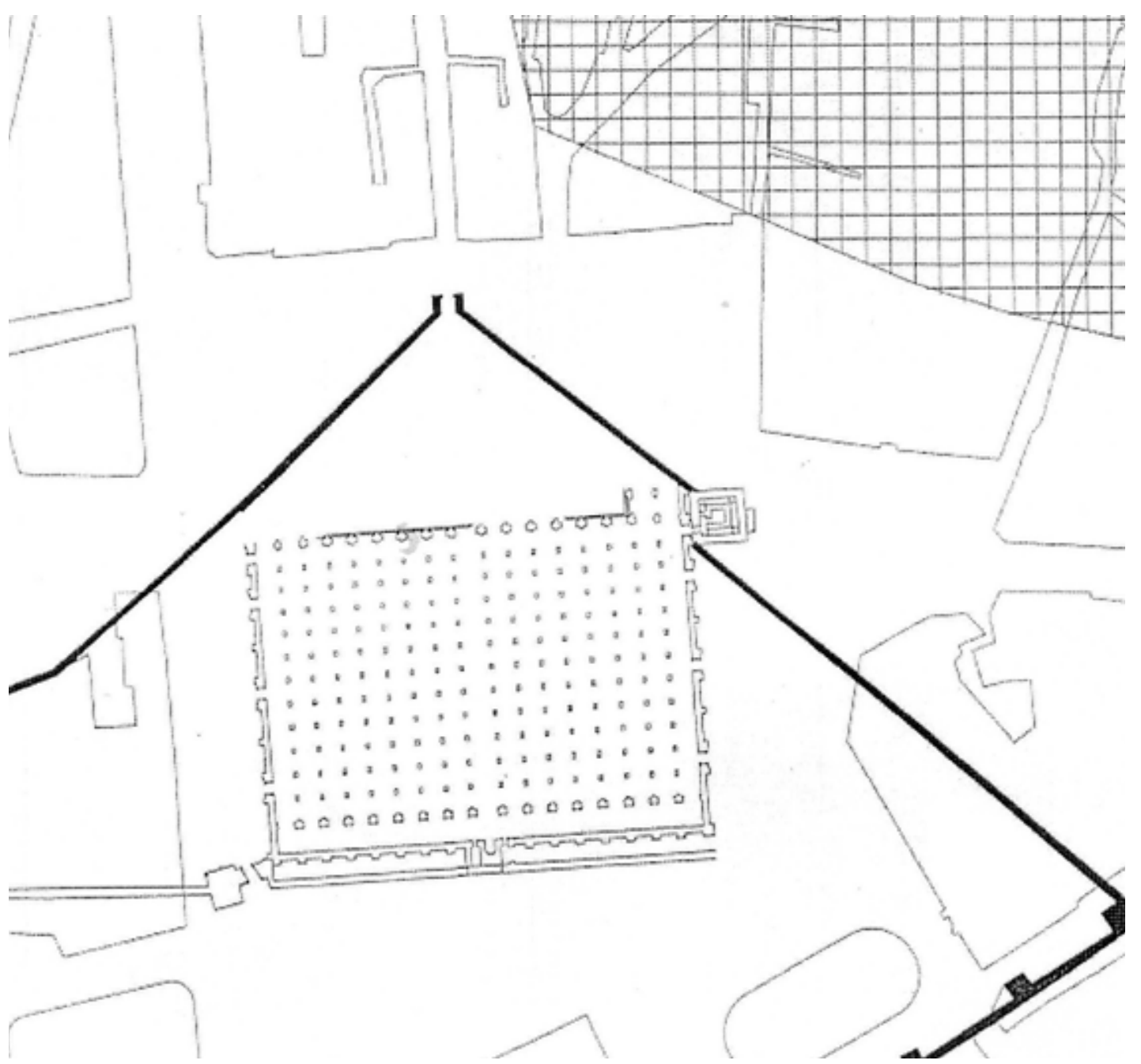

Figura 8. Hipótesis sobre los lienzos erigidos por orden de Abū Ya'qūb el 13 de safar del año 580/26 de mayo de 1184 según Jiménez Sancho (2002).

la hipótesis acerca de la existencia de una puerta monumental inacabada ${ }^{14}$. Dicha puerta, de la que en el año 2004 se documentó la otra torre, representaría el testimonio de los planes de Abū Ya'qūb de militarizar la mezquita aljama, al incluirla dentro de un recinto configurado por sendos lienzos que confluían, a modo de tenaza, en la Puerta del Per-

14 En las gradas de la calle Alemanes se documentó un muro de sillares de piedra alcoriza, tallados ex profeso, alguno de los cuales presentaban una marca incisa en forma de $\mathrm{X}$ y estaban unidos con un mortero de cal, que contaba con tres escarpas y una mocheta hacia el norte. Aunque la desconexión entre dicha estructura y la Puerta del Perdón es evidente, su excavador considera que esta rompe y, por tanto, es posterior a aquella (Jiménez Sancho, 2002b; 2002d, 340-341). Por el contrario, el Dr. Cómez ha sostenido que la mencionada estructura correspondería a una primitiva fase de la Puerta del Perdón (Cómez, 2012, 207-208). dón (figura 8) (Jiménez Martín, 2007b, figura 2). El occidental, del que formaría parte el ya mencionado en la Plaza del Cabildo, se ha documentado en los últimos años en diversos puntos a lo largo de su trazado, como en la Avenida de la Constitución, en las Gradas de la Catedral a la altura del acceso de la iglesia del Sagrario y en el sahn de la aljama almohade $^{15}$. Por su parte, el oriental partiría al pie de la

15 En el año 1998 se detectó al sudeste de la puerta de la iglesia del Sagrario, donde se marcó una línea incisa en el pavimento con la alineación de la muralla. En septiembre de 2006 aparecieron, en el seguimiento arqueológico de las obras de la Avenida de la Constitución, el lienzo y una torre (Hunt, 2008, 234-235). Por último, en la intervención arqueológica en el Patio de los Naranjos, llevada a cabo en el año 2000, se documentó un lienzo de argamasa de cal, tierra y grava, con una anchura de 2’30 m y cajones de $90 \mathrm{~cm}$ de 
torre occidental del primitivo acceso del Alcázar en dirección al alminar, documentado en las obras de saneamiento en la lonja de la Puerta de los Palos de la Catedral en 2001 (figura 9).

La muerte de Abū Ya'qūb frustró el citado proyecto de militarización de la aljama, al que renunció Abū Yūsūf, el nuevo califa. Este se limitaría a mantener la muralla occidental hasta su contacto con el sahn, mientras que a levante erigiría una nueva muralla que, paralela al muro oriental de la aljama, alcanzaba la futura Giralda ${ }^{16}$. En este punto se abriría la Puerta de los Palos, que conectaba la medina con la alcazaba (lámina 5) ${ }^{17}$. Asimismo, sería ahora cuando se erigiría el lienzo que discurría paralelo a la qibla hasta la Puerta de San Miguel, excavado en la Acera de Levante a la altura de la Sala Capitular, en la Puerta de San Cristóbal y en el Patio de los Limoneros, (Jiménez Martín, 2000, 58; 2002, 479).

En el mismo pasaje de al-Salāt previo a la campaña de Santarem, que habría de costarle la vida, Abū Ya'qūb ordenaba “(...) edificar una atarazana para las naves, que llegase desde la muralla de la alcazaba que da sobre el río en la bāb al-Qatai hasta el pie más bajo, contiguo a la bāb al-Kuhl" (Ibn Sāhib al-Salāt, 1969, 200). Es también Alfonso Jiménez a quien debemos la propuesta de localización de las atarazanas almohades, en el mismo lugar en el que Alfonso X erigió las suyas en 1252 (figura 6) (Jiménez Martín, 1981, 18-19; 1996, 149)18. Sin embargo, las excavacio-

altura (Jiménez Sancho, 2002e, 368; 2003).

16 Para el trazado de este lienzo contamos con los Planos $A, B$ y $C$ de la planta de distribución del Corral de los Olmos, 1781, del arquitecto Manuel de Carranza (Falcón, 1979; Granero, 1992, láminas 47, 48 y 49).

17 En el corte III de la Acera de Levante de la Catedral se documentaron sendas alineaciones de sillares, con una desviación de unos $8^{\circ}$ respecto a la cara oriental de la Giralda, cuya ejecución técnica es muy similar a la cimentación del propio alminar y que conforman un vano de 2'60 m de luz, correspondientes a la denominada Puerta de los Palos (lámina 5) (Tabales et alii, 2001, 401; 2002, 142). Además en la fachada oriental de la Giralda son evidentes las huellas de las aguas sobre la fábrica originadas por el entronque de dicha puerta, de cuyo aspecto, a mediados del siglo XVIII, da cuenta el óleo Carro del fuego de Domingo Martínez, conservado en el Museo de Bellas Artes de Sevilla (Serrera et alii, 1989, 218).

18 En este sentido, Torres Balbás fue el primero en sostener que las atarazanas almohades sirvieron como modelo a las alfonsíes (Torres Balbás, 1946, 185 y 196), mientras que Julio González afirmó que estas no serían más que una reconstrucción de aquellas (González, 1951, 518-520). Por el contrario, la propuesta del Dr. Cómez de localizar las atarazanas almohades en el Arenal, entre el Postigo del Aceite y

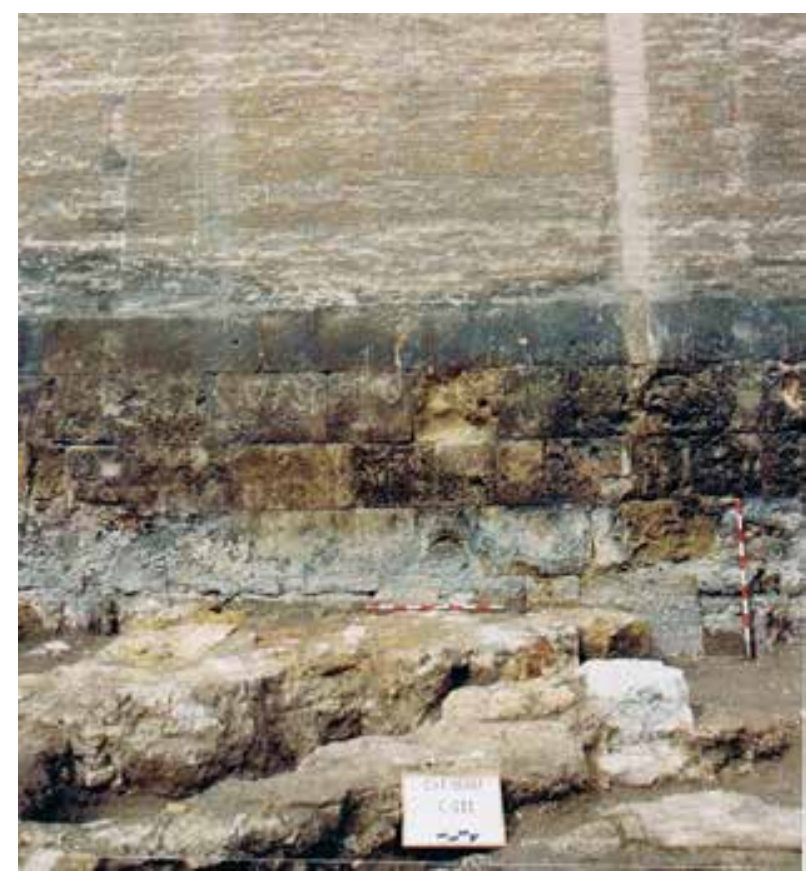

Lámina 5. Puerta de los Palos documentada en el corte III de la Acera de Levante de la Catedral (fotografía cortesía de Miguel Ángel Tabales).

nes arqueológicas llevadas a cabo en la década de los noventa del pasado siglo no pudieron documentar resto alguno de las mismas (Amores y Quirós, 1997; 1999; Quirós, 1999). De este modo, en los últimos años los doctores Enrique Domínguez (Domínguez, 2008, 239-242) y Gregorio Mora (Mora, 2013, capítulo 5,143 ss.) han defendido que las atarazanas ya'qubíes fueron erigidas en el recinto de la Casa de la Moneda (figura 10) ${ }^{19}$. Para ello el principal argumento lo constituye la existencia de dos grandes

la Puerta de Arenal (Cómez, 2000; 2014, 221), presenta el severo inconveniente, ya observado por los Drs. Domínguez y Mora, de resultar contradictorio con el planteamiento urbanístico ya'qubí de concentrar todas las instalaciones vinculadas al sultan almohade en el sector meridional de la medina, incluida una evidente intención de segregación frente a la población sevillana (Domínguez, 2001, 187). En cuanto a la hipótesis de que las atarazanas nunca llegaran a construirse (Cómez, 2014, 222-223), resulta de imposible verificación.

19 En un principio, este recinto, correspondiente al número XI en la nomenclatura del Dr. Tabales, fue identificado por el propio Alfonso Jiménez (Jiménez Martín, 1981, 18) con “(...) las villas y casas para el gobierno (...)" que el sayyid Abū Hafs, hermano del califa Abū Ya'qūb, edificó "(...) sobre el río de Sevilla, fuera de la bāb al-Kuhl (...)" (Ibn Sāhib al-Salāt, 1969, 188) (figura 6). Esta localización ha sido descartada con posterioridad por el mismo investigador, en detrimento del cercano Corral de Jerez (Jiménez Martín, 2000, 53-54). 


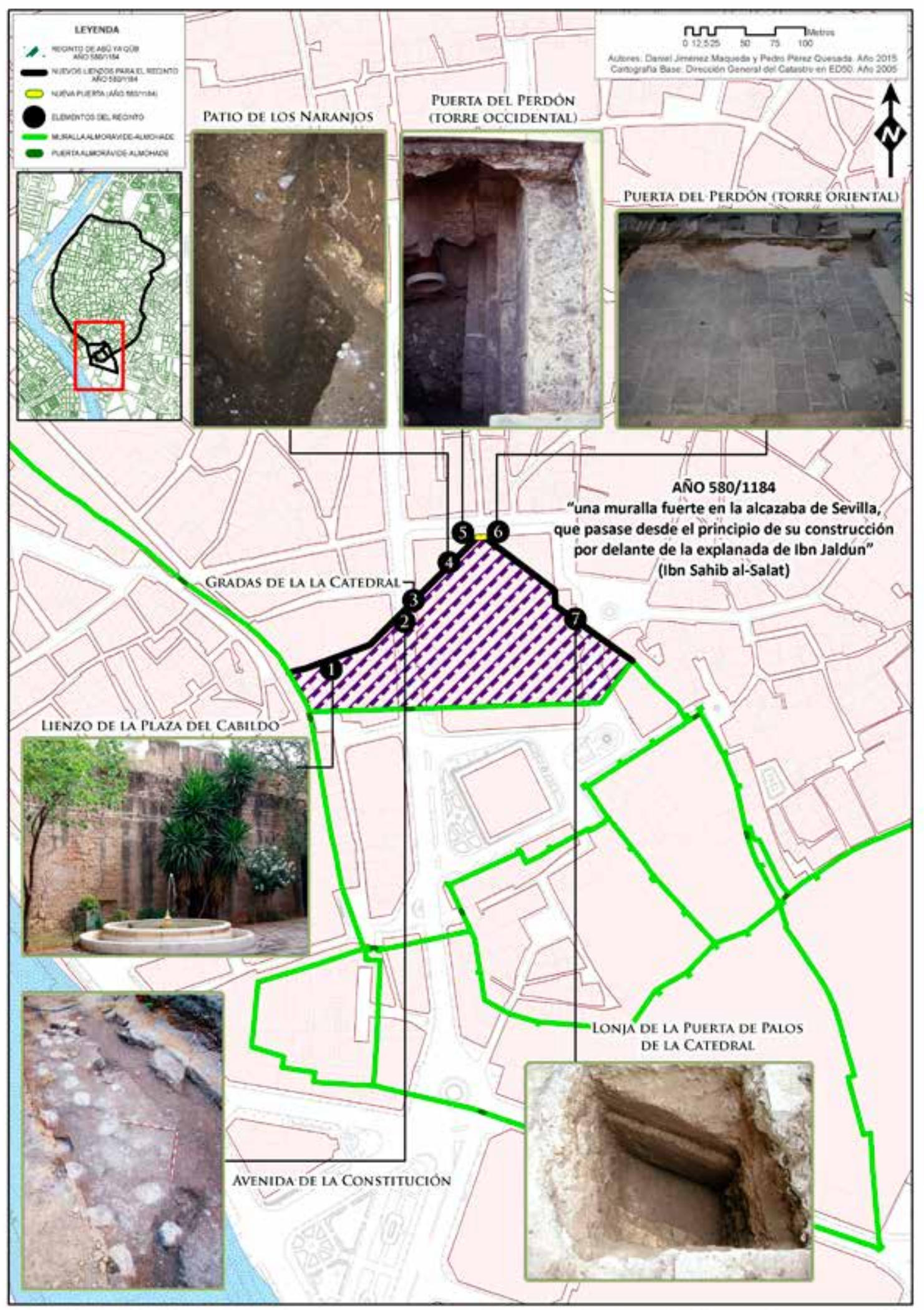

Figura 9. Hipótesis sobre los lienzos erigidos por orden de Abū Ya'qūb el 13 de safar del año 580/26 de mayo de 1184 basado en Jiménez Martín (2007). 
vanos hacia el río, construidos con jambas y rosca escarzana de cantería y más de $7 \mathrm{~m}$ de luz, medidas apropiadas para la entrada y salidas de las naves de guerra de la época.

Por su parte, Ibn 'Abd al-Malik al-Marrākuš̄̄ afirma que, en la tarde del martes 19 de $\hat{y} u m \bar{a} d a$ II del año 597/26 de marzo de 1201, tuvo lugar una inundación, que volvió a derribar sendos lienzos de la muralla por el lado del río “(...) entre la puerta de Triana y la de al-Mu'addin y en el lugar conocido bajo el nombre de al-Daqqāqin, donde se halla la Alberca; la fuerza de la riada derribó casi $40 \mathrm{Ba}^{\prime}(. .$.$) "(Salem, 1979-1980, 180) { }^{20}$. Aunque se ha afirmado que la muralla sería reparada de manera provisional el mismo año de su derribo (Idem), carecemos de cualquier dato que permita corroborar o desmentir dicho extremo, si bien es cierto que el temor a los efectos de una nueva inundación haría recomendable una intervención inmediata (lámina 6).

Las últimas intervenciones de los Unitarios en el recinto sevillano de las que tenemos constancia en las fuentes árabes se fechan, según el Rawd alqirtās y la obra al-Dajīra al-Saniyya, en el año 617/1220-1221, cuando "se edificó la Torre del Oro, a la orilla del río de Sevilla”, y en 618/1221-1222, cuando "se repararon los muros de Sevilla, se construyó el recinto de las fortificaciones y se hizo el foso alrededor del recinto" (Ibn Abī Zar', 1964, 523). La Torre el Oro cuenta con una abundante bibliografía, (Falcón, 1983; Valor, 1991, 251 ss.; 2008a, 81-83), por lo que aquí nos interesa son sus implicaciones urbanísticas mediante la conexión de la torre con el recinto amurallado (lámina 7). En cuanto al segundo pasaje, la historiografía sevillana ha identificado la mencionada reparación con el recrecimiento en altura de la cerca (lámina 8$)^{21}$, mientras

20 Para la localización de la Puerta de Triana (Valor, 1991, 135; Jiménez Maqueda, 1999a, 149). En cuanto al emplazamiento de la $b \bar{a} b$ al-Mu'addin, la mayor parte de la historiografía sevillana la identifica con la Puerta de Goles (Valencia, 1988, 553). Alfonso Jiménez constituye la excepción, pues lo hace con la del Arenal, en virtud de la mención a "la Alberca", resto del paleocauce del Guadalquivir que en época moderna se conocerá como la Laguna de la Pajería (Jiménez Martín, 2000, 59).

$21 \mathrm{La}$ primera mención a dicho recrecimiento corresponde a Rodrigo Caro, quien en el siglo XVII afirmaba ya que "Vese por muchas partes deste muro, añadido, y sobrepuesto con tanta unión y fortaleza de la misma materia, que para advertirlo, es necesario mirarlo con atención" (Caro, 1634, folio 20, columna 1). Este recrecimiento, consistente que el recinto de fortificaciones no sería otro que el antemuro o acitara (lámina 9) ${ }^{22}$.

\section{EN EL CONTEXTO DE LA ARQUITECTURA MILITAR} DE AL-ANDALUS.

En este apartado, nuestra propósito es el de situar las fortificaciones con las que los almohades dotaron a madīnat Išbīlia en el contexto de la arquitectura militar de al-Andalus. Para ello, estableceremos una nítida distinción entre los diversos recintos erigidos en el Alcázar y los dispositivos poliorcéticos con los que los almohades reforzaron el recinto sevillano.

en incrementar la altura de la cerca en uno o dos cajones y su correspondiente parapeto y merlatura, se ha documentado, hasta la fecha, en la murallas de la Macarena (Campos et alii, 1987; Campos y Moreno, 1988; Pozo, 2008, 165-166), en los Jardines del Valle (Moreno et alii, 1987), en María Auxiliadora 37 (Pozo, 2003), en María Auxiliadora 39 (Herce, 1996), en Sol 128 y 130-134 (Herce y Franco, 1997), en Sol 122 (Alba y Tabales, 2008), en la Puerta del Osario (De visu), en Menéndez y Pelayo 43-45 (Tabales, 2002b), en el Lienzo del Agua (Tabales, 2002c, 113-115) y en la Puerta Real (Ramírez y Vargas, 1995).

22 Como quiera que no tenemos constancia alguna de su presencia en la cerca sevillana, no incluimos en nuestro estudio las denominadas albarranas de flanqueo (MoraFigueroa, 1992, 52; 1994, 195). Con todo, la utilización de torres de planta cuadrada o rectangular, unidas al adarve por puentes o pasadizos, representa un elemento peculiar de la poliorcética almohade andalusí (Torres Balbás, 1942b, 219; 1949, 13; 1955, 21; 1971, tomo II, 590; Terrasse, 1954, 24; Acién, 1995, 39; Pavón, 1999, 252-254; Gurriarán y Sáez, 2002, 607, 608 y 610; Azuar, 2004, 68 y 71; Márquez y Gurriarán, 2008, 121-123; Azuar y Ferreira, 2014, 406). Así, están presentes en las fortificaciones de Trujillo (Valdés, 1991, 554-556; 1998, 181-183), Cáceres (Torres Balbás, 1948, 464466; Valdés, 1991, 554; Márquez y Gurriarán, 2003), Santa Cruz en la provincia de Cáceres (Gilotte, 2008, 83; 2009, 66), la alcazaba de Badajoz (Torres Balbás, 1941a, 179, 180 y 198; Valdés, 1999, 159-160), la alcazaba de Mérida (Valdés, 1991, 554-556; Alba, 2001, 284), Reina (Garrido, 1989, 273), Calatrava la Vieja (Retuerce, 1995, 95-96; 1996, 214; 1998b; Retuerce y Hervás, 2002, 316), Alcácer do Sal (Pavón, 1993, 16-17), Elvas (Correia, 2002, 363), Moura (Macías, 1993, 128-129), Silves (Gomes, 2002; 2003; 2006; 2009), Loulé (Martins y Matos, 1971, 229 y 232), los castillos del Algarve portugués de Salir (Catarino, 1994a; 1997, 456; 2001, 697698) y Paderne (Catarino, 1994b), el recinto onubense de Zufre (Jiménez Martín, 2005, 131), Écija (Hernández et alii, 1951, 219, 222 y 223; Carrasco y Vera, 2003; Sáez et alii, 2002; 2004, 111, 112 y 114), Belalcázar (Pavón, 1989, 559; León, 2003, 191-192) y, tal vez, Granada (Orihuela, 1995, 198), Córdoba (Murillo et alii, 1999, 71; León y Blanco, 2010, 708) o Málaga (Rambla et alii, 2002, 815). 


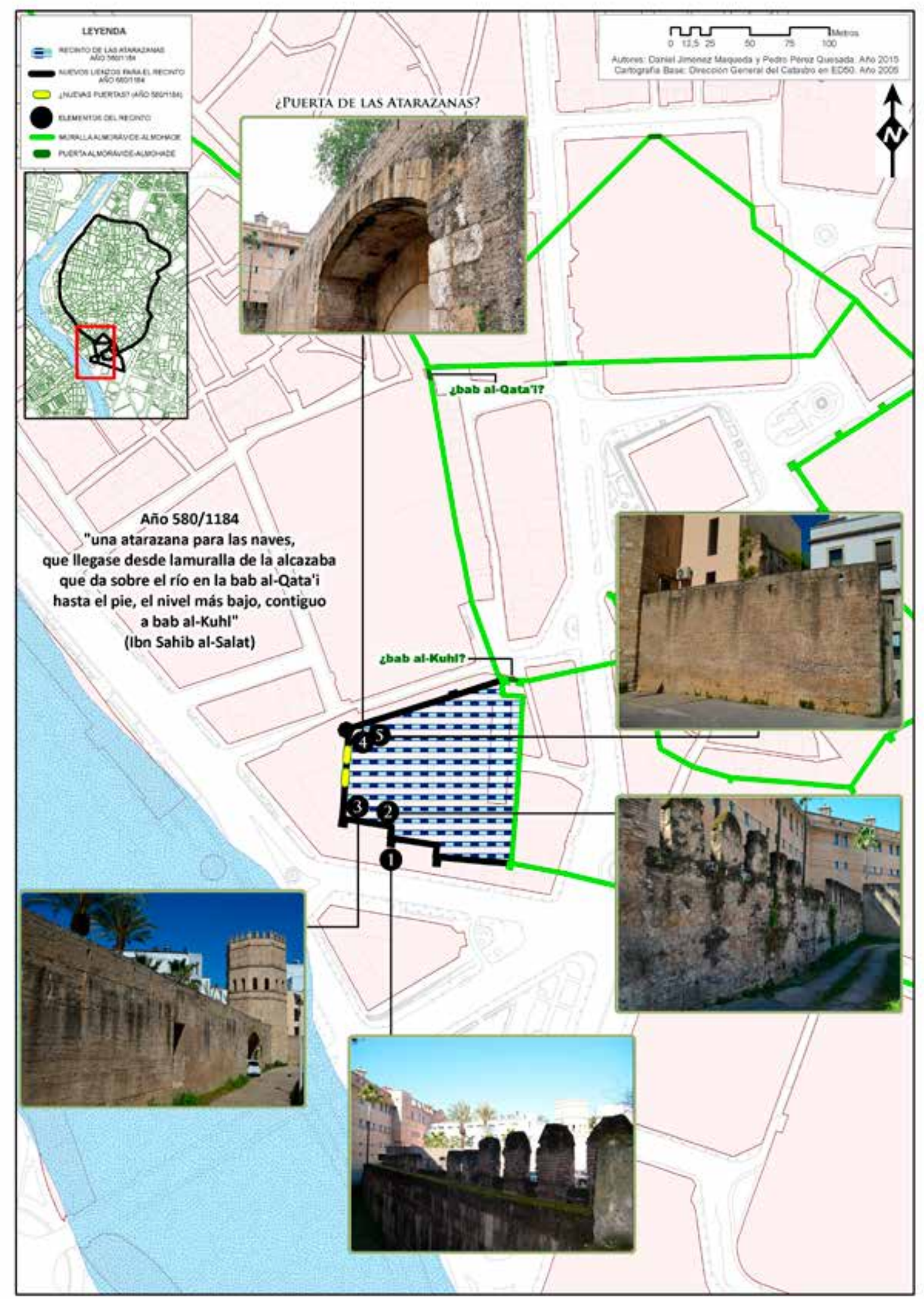

Figura 10. Hipótesis sobre el emplazamiento del recinto de las atarazanas erigidas por orden de Abū Ya'qūb el 13 de safar del año 580/26 de mayo de 1184. 


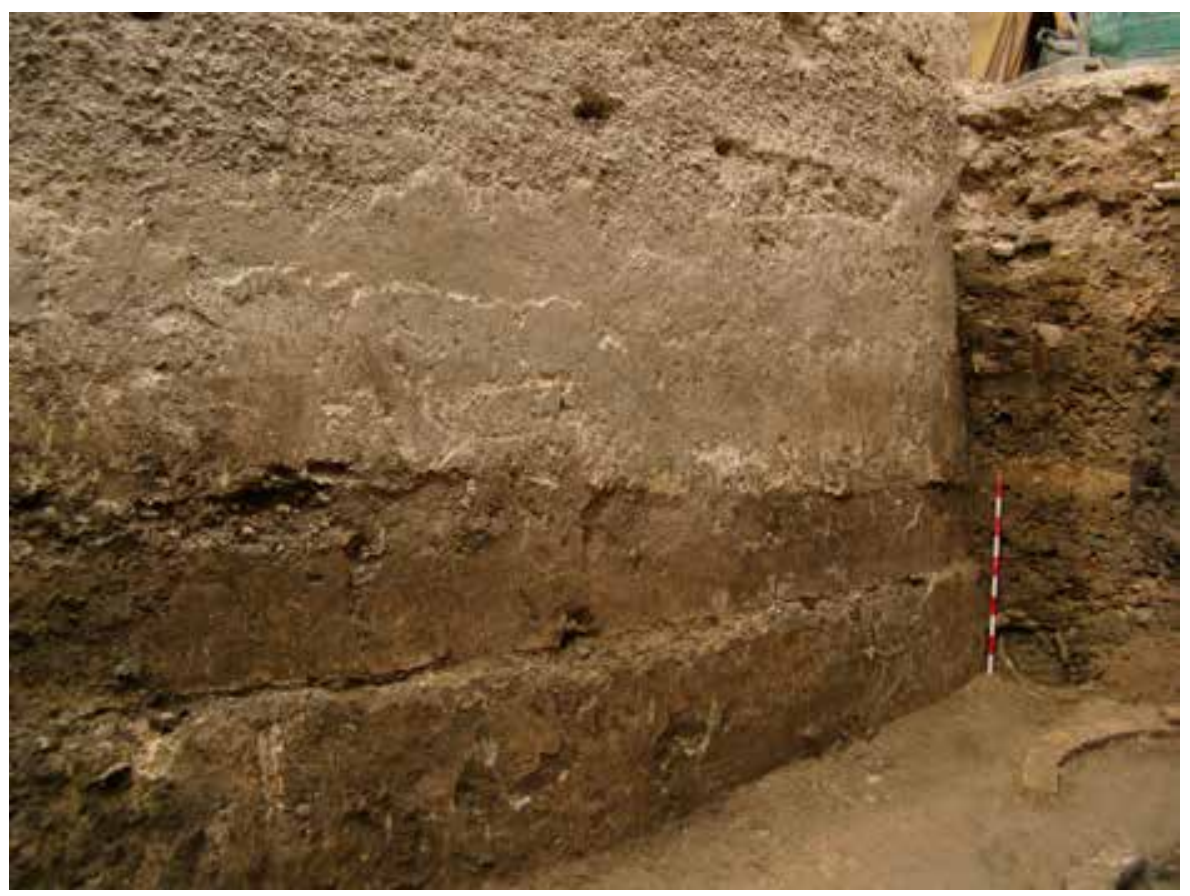

Lámina 6. Lienzo documentado en la intervención arqueológica efectuada en Zaragoza 8 (fotografía cortesía de Enrique Domínguez).

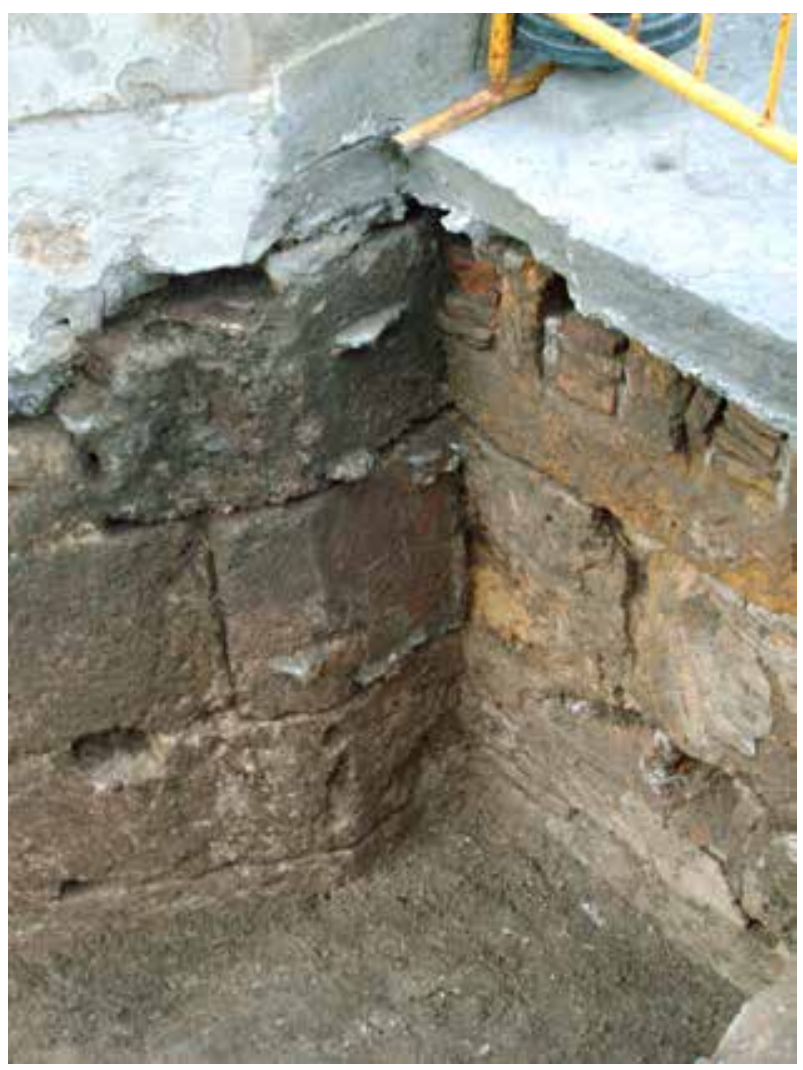

Lámina 7. Detalle del punto de contacto entre la coracha y el cuerpo principal de la Torre del Oro (fotografía cortesía de Enrique Domínguez).

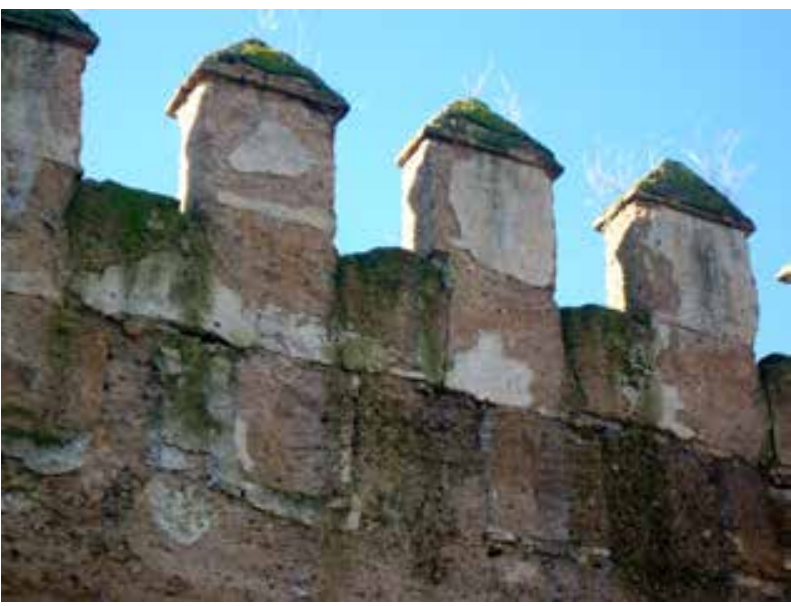

Lámina 8. Superposición de las dos fases de la muralla en la Macarena. Sector de la Puerta de Córdoba (fotografía de Daniel Jiménez). 


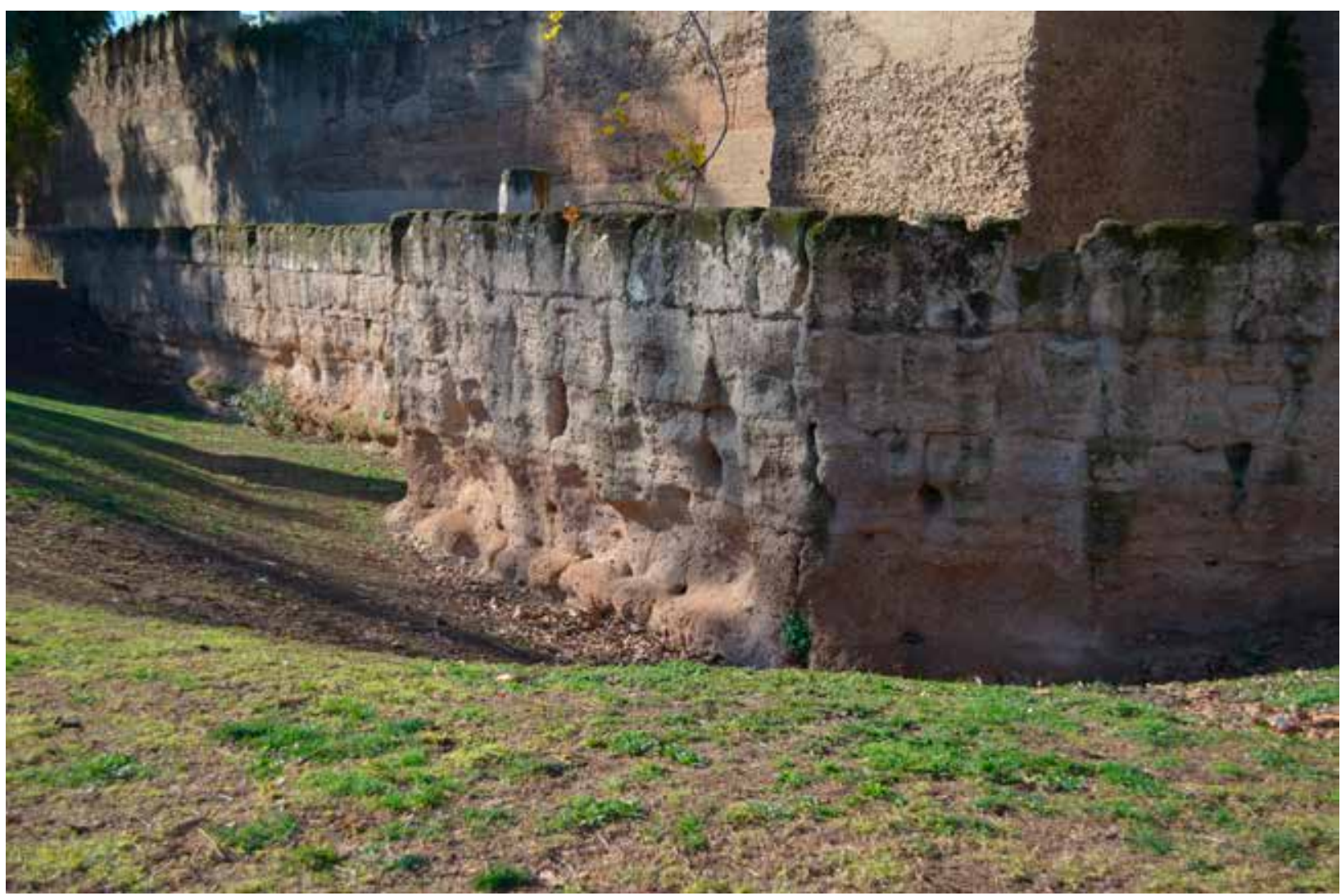

Lámina 9. Antemuro y foso en la Macarena. Sector de la Puerta de Córdoba (fotografía de Daniel Jiménez).

\subsection{TORRES POLIGONALES.}

La presencia de torres poligonales, que, en sentido estricto, no son más que un tipo de albarrana ${ }^{23}$, supone un elemento característico de la arquitectura militar almohade andalusí (Torres Balbás, 1949, 13; 1955, 21-22; 1971, tomo II, 580; Acién, 1995, 39; Pavón, 1999, 269-273; Gurriarán y Sáez, 2002, 607-608; Valdés, 2003, 134-135; Azuar, 2004, 68; Márquez y Gurriarán, 2008, 121-123; Azuar y Ferreira, 2014, 406).

Están presentes en las fortificaciones extremeñas de Cáceres (Torres Balbás, 1948, 464-466; Márquez y Gurriarán, 2003, 73-78), la alcazaba

23 En cuanto al antemuro, aparte de las murallas de la Macarena, hasta el momento se ha documentado en María Auxiliadora 37 (Ortega, 2002; Pozo, 2003), Menéndez y Pelayo 43-45 (Tabales, 2002b), Menéndez y Pelayo 19 (Tabales, 2001b), Menéndez y Pelayo 5-7 (Sardá et alii, 2003), la Puerta de Marchena del Alcázar (Tabales, 2002a; 2002c), la Puerta de la Alcoba del Alcázar (Tabales, 2002a; 2002c), la calle San Fernando (Hunt et alii, 2010), las Reales Atarazanas (Amores y Quirós, 1999; Quirós, 1999), Julio César 14 esquina Canalejas (Carrasco y Vera, 2001), Aguiar 5-7 (Pozo y Somé, 2002) y la Puerta Real (Ramírez y Vargas, 1995). de Badajoz (Torres Balbás, 1941a, 182-185; Valdés, 1999, 160; Márquez y Gurriarán, 2012) y el castillo de Reina (Garrido, 1989, 273), en las fortalezas y recintos portugueses de Alcácer do Sal, Elvas (Correia, 1996, 84; 2002), Juromenha, Serpa, Moura ${ }^{24}$, Silves (Gomes, 2002; 2006, 16; 2009; Gonçalves, 2009) y Tavira (Paulo, 2009, 583-584), en el recinto onubense de Niebla (Jiménez Martín, 1980, 23; Pavón, 1980, 412; 1996a, 19 y 25; Pérez et alii, 1998, 350), en los gaditanos de Jerez de la Frontera (Pavón, 1981; Menéndez y Reyes, 1987a; 1987b), Tarifa (Sáez, 2003, 95 ss.) y Algeciras (Torremocha et alii, 2002, 460-461), en los sevillanos de Sanlúcar la Mayor (Medianero, 1993, 263; Valor, 2004, 157), Écija (Hernández et alii, 1951, 218-222; Sáez et alii, 2002, 257-258; 2004, 107 ss.) y Marchena (Ravé, 1993, 49-50; Bellido, 2010, 129-132), en las fortalezas malagueñas de Monda (Acién y Rambla,

24 Aunque no quedan restos de las torres poligonales de Juromenha, Serpa y Moura, las ilustraciones del Livro das fortalezas de Duarte de Armas, realizado a comienzos del siglo XVI, no dejan lugar a dudas acerca de su existencia (Armas, 1997). 
1991-1992) y Bentomiz, y, por último, en los recintos jiennenses de Andújar (Eslava y Córcoles, 1980; Choclán y Castillo, 1991; Palomino, 1998) y Arjona (Eslava, 1986).

En relación a las torres poligonales, en las fortificaciones de Sevilla contamos con las torres del Oro (Torres Balbás, 1934a; 1934b; Falcón, 1983; Valor, 1991, 251 ss.), Blanca (Valor, 1991, 162-165)25, de la Almenilla, en el ángulo noroccidental del recinto ${ }^{26}$, de la Plata (Torres Balbás, 1934a; Valor, 1991, 240 ss.; Valor y Casquete, 1991) y de Santo Tomás o Abdelaziz (Valor, 1991, 199), si bien para las dos últimas hay quienes sostienen una cronología cristiana (Domínguez, 2008, 243-244; Amores, 2014) ${ }^{27}$.

En relación a la presencia de torres poligonales en las fortificaciones almohades, se pueden hacer algunas precisiones cronológicas, pues en varios casos resulta evidente su tardía incorporación a las mismas. Así acontece, por ejemplo, en las de Silves y Alcácer do Sal, recuperadas por al-Mansūr en $587 / 1191$ (Huici, 1956, 355-357), y en la de la calle Calzada de Écija, donde el espigón que la conectaba con el lienzo de muralla seccionó en sentido vertical la cámara de una de las torres y su cimentación (Hernández et alii, 1951, 212 y 219; Collado et alii, 2001). Por el contrario, son mayoritarios los ejemplos a los que no es posible proporcionar una datación tan ajustada.

25 La aportación más reciente a la historiografía de la Torre del Oro la constituye la agria polémica entre Fernando Amores y Rafael Cómez acerca de la cronología del segundo cuerpo, obra de Pedro I para aquél y almohade para este último (Amores, 2007; 2010; 2014; Cómez, 2008).

$26 \mathrm{La}$ primera mención a la misma figura en un documento de los Papeles del Mayordomazgo, fechado en 1386, en el que se afirma: "(...) pasado el alcaçar de la dicha puerta de macarena, la torre del almenilla" (Collantes de Terán, 1968, 53, documento 33). Por su parte, Luis de Peraza se refiere a ella, a comienzos del segundo tercio del siglo XVI, en estos términos: “(...) la Almenilla, que es una torre junto a Guadalquivir (...), que está poco delante de la Puerta de Macarena" (Peraza, 1979, 86; 1997, tomo II, 354). Sin embargo, no tenemos la certeza de que se trate de una torre poligonal.

27 En un reciente artículo, Fernando Amores sugiere una cronología cristiana para la torre de Abdelaziz o Santo Tomás, en función de elementos tales como el despiece de cantería de sus ángulos, realizados en aparejo isodomo procedente de una única cantera, el empleo del ladrillo en los paños centrales, el diseño evolucionado de los canes o los datos inéditos proporcionados por la intervención arqueológica llevada a cabo en el interior de la vivienda que se le adosa (Amores, 2014, 31, nota 41).

\subsection{Antemuro.}

A pesar de que la historiografía tradicional defiende su difusión en al-Andalus en el siglo V/ XI (Torres Balbás, 1951, 474 ss.; Pavón, 1992, 311$312)^{28}$, el empleo de antemuros o acitaras que circundan el muro principal supone otro de los elementos característicos de la arquitectura militar almohade andalusí (Jiménez Martín, 1995a, 176; Acién, 1995, 39; Pavón, 1999, 281-282; Gurriarán y Sáez, 2002, 608 y 610; Valdés, 2003, 134-135; Azuar, 2004, 69; Azuar y Ferreira, 2014, 407).

En este sentido, está presente en la fortaleza de Calatrava la Vieja, en la provincia de Ciudad Real (Retuerce, 1996, 214; Retuerce y Hervás, 2002, 316), Alcácer do Sal (Carvalho et alii, 2007, 6162), la alcazaba de Badajoz (Valdés, 1999, 160-161), Cáceres (Márquez y Gurriarán, 2003, 64-65), Tavira (Maia, 2006), Jerez de la Frontera (Menéndez y Reyes, 1987a; 1987b; Montes y González, 1990; Aguilar, 1995; Barrionuevo y Aguilar, 2001), Tarifa (Torremocha y Sáez, 1998, 193), Algeciras (Ibídem, 175), Écija (Hernández et alii, 1951, 212, 216 y 219; Romero y Carrasco, 1997; Carrasco y Vera, 2003; Sáez et alii, 2002, 255; 2004, 100-101), Marchena (Bellido, 2010, 107-109), la fortaleza cordobesa de Belalcázar (León, 2003, 191-192) y los recintos de Málaga (Rambla et alii, 2002, 815; Rambla et alii, 2003, 141-142; Arancibia, 2004; Fernández, 2004; Melero, 2009; Rambla, 2010), Murcia (Jiménez y Sánchez, 1997), Valencia (Pascual y Martí, 2002, 306; Díes et alii, 2004) o, tal vez, Granada (Orihuela, 1995, 198; Orihuela y Rodríguez, 2004).

\subsection{CORACHAS.}

Las corachas constituyen un elemento característico de la poliorcética almohade andalusí (Torres Balbás, 1971, tomo II, 537; Acién, 1995, 39; Azuar, 2004, 68 y 71; Azuar y Ferreira, 2014, 406). Están presentes en la alcazaba de Badajoz (Torres Balbás, 1941a, 181; Valdés, 1999, 157-158), Cáceres (Márquez y Gurriarán, 2003, 90; Sánchez, 2008), Alcácer do Sal (Carvalho et alii, 2007, 62), Silves (Gonçalves, 2010) o Algeciras (Torremocha y Sáez, 1998, 176$177)^{29}$.

28 Según el testimonio de al-Bakrī, las fortificaciones erigidas por 'Abd al-Rahmān III en Ceuta ya habrían dispuesto de este dispositivo poliorcético (al-Bakrī , 1913, 202203; Torres Balbás, 1951, 460 y 477; Torremocha y Elboudjay, 2001, 297; Hita y Villada, 2002, 494).

29 Se ha defendido su presencia en las fortificaciones emirales de Calatrava la Vieja (Retuerce y Lozano, 1986, 
A este respecto, debemos señalar que entendemos por coracha el "adarve de doble antepecho que, partiendo del recinto fortificado, permite el acceso protegido, o al menos el control, a/de un punto no muy lejano, normalmente para realizar la aguada" (Mora-Figueroa, 1992, 54; 1994, 85). Se trata, de este modo, de uno de los tipos, junto con las galerías subterráneas o minas, del dispositivo poliorcético al que se ha definido como coracha-agua (Pavón, 1986, 334-335; 1990, 366-367).

Su empleo en la cerca sevillana hay que retrasarlo hasta 617/1220-1221, cuando se edificó la Torre del Oro, a la que daba acceso una que partía desde el Alcázar (Amores et alii, 1987; Domínguez y Amores, 2009). A esta habría que añadir la que unía la torre de la Almenilla con el ángulo noroccidental del recinto y constituiría el cierre septentrional del Arenal (Jiménez Maqueda, 1999a, 192-193; Domínguez, 2008, 238).

\subsection{CÁMARAS ABOVEDADAS EN LAS TORRES.}

La existencia de torres que presentan cámaras abovedadas a la altura del adarve constituye un rasgo característico de la arquitectura militar almohade (Jiménez Martín, 1980, 24; 1995a, 176; 1998, 660; Gurriarán y Sáez, 2002, 608) ${ }^{30}$.

Está presente en Cáceres (Márquez y Gurriarán, 2003, 94 y 102), la alcazaba de Badajoz (Torres Balbás, 1941a, 180; Valdés, 1999, 159; Márquez y Gurriarán, 2012), Niebla (Jiménez Martín, 1980, 24; Pérez et alii, 1998, 349; Gómez y Beltrán, 2006; Campos et alii, 2006, 274 y 367), Jerez de la Frontera (Aguilar, 2000, 99 y 105), Tarifa (Torremocha y Sáez, 1998, 192), Ecija (Hernández et alii, 1951; Sáez et alii, 2002; 2004), el recinto cordobés de Palma del Río (Córdoba, 2004, 127), Málaga (Arancibia, 2004) o Andújar (Eslava y Córcoles, 1980, 35-36).

59-61; Retuerce, 1998b; Retuerce y Hervás, 2002, 313; Zozaya, 1992, 71) y Toledo (Delgado, 1991) y en las califales y taifas de Granada (Gómez, 1951, 262; Seco de Lucena, 1968; Pavón, 1986, 347 ss.; 1990, 374-377; Orihuela, 1995, 195-196; Orihuela y Rodríguez, 2004).

30 Sin embargo, no son infrecuentes los recintos almohades cuyas torres carecen de cámaras abovedadas, si bien no se puede descartar su desaparición. Así se documenta, por ejemplo, en las del recinto onubense de Tejada la Nueva ( $D e$ visu), en las de los sevillanos de Sanlúcar la Mayor (Medianero, 1993, 265; Valor, 2004, 157), San Juan de Aznalfarache (Valor, 2004, 155) o Lora del Río (Valor, 1999, 731) o en los cordobeses de El Vacar (De visu) o Belalcázar (León, 2003, 190).
En Sevilla se documentan en algunas de las torres del recrecimiento de la cerca urbana (Collantes de Terán, 1977, 105; Valor, 1991; 2008a, 54-55; 2009, 201-202; Pozo, 2008, 166), así como en las de diversos recintos del Alcázar para los que se sostiene una datación almohade (Valor, 1991; Tabales, 2002c, 99, 110 y 122).

\subsection{Puertas.}

La historiografía tradicional defiende que las puertas en recodo aparecieron en al-Andalus en el siglo V/XI (Torres Balbás, 1960b, 427, 440 y 441; Pavón, 1992, 320; 1996b, 167 ss.; 1999, 403 y 405). Sin embargo, hay quien retrasa su llegada hasta el período almohade y constituye otro de los elementos característicos de sus fortificaciones (Valdés, 2003, 133 y 135) ${ }^{31}$.

Estas puertas se caracterizan por estar abiertas en una torre saliente de la muralla, con el acceso en uno de sus costados. Se ha documentado así tanto la existencia de un espacio a cielo abierto, como en la puerta Monaita de Granada (Abū, 2001) o en la de Córdoba de Sevilla (Guerrero, 1953; Valor, 1991, 172-176), como la de dos pasadizos normales cubiertos con bóvedas de cañón, en cuya intersección se sitúa una baída, como en la Puerta Nueva o de las Pesas de Granada (Pavón, 1999, 453) o la primitiva puerta de la Alcazaba de Málaga (Torres Balbás, 1944, 182).

En este sentido, aunque Torres Balbás situó en el siglo V/XI sendas puertas de la Alcazaba de Málaga (Ibidem, 182) y las puertas Monaita y Nueva o de las Pesas (Torres Balbás, 1941b, 442; 1960b, 427), la

31 Se pueden mencionar algunos ejemplares polémicos, cuya cronología se remonta al siglo III/IX, como la puerta de acceso a la medina de Calatrava la Vieja (Retuerce y Lozano, 1986, 58 y 60; Retuerce, 1995, 94; 1998b; Retuerce y Hervás, 2002, 313; Zozaya, 1992, 71), la Puerta de Alcántara de Toledo (Delgado, 1991; 1999, 52-54; Zozaya, 1992, 71) o la Puerta del Barrio en la localidad soriana de Ágreda (Retuerce, 1998a); a los siglos IV/IX-V/X, como la del castillo soriano de Gormaz (Zozaya, 1984; 2001; Pavón, 1996b, 163; Almagro, 2008, 63); y al siglo V/X, como la de Madinnat al-Zahrā' (Gómez, 1951, 73; Torres Balbás, 1957, 441-442; Hernández, 1985, 18 ss.; Valdés, 1988, 571; Vallejo, 2004, 78).

En cuanto a su origen, se han formulado diversas hipótesis, pues hay quienes defienden que se encuentra en las fortificaciones bizantinas del norte de África de los siglos VI y VII (Diehl, 1896; Pringle, 1981) y quien, por el contrario, rechaza esa posibilidad, sosteniendo que las más antiguas las constituyen las cuatro del recinto circular de Bagdad, erigido por el califa al-Mansūr entre los años 145/762 y 147/765 (Creswell, 1940, 11, 26, 28 y 392; 1952; 1958). 
posibilidad de que esta última fuese almorávide no le pasó desapercibida (Torres Balbás, 1952, 424), tal y como han señalado algunos investigadores granadinos (Orihuela, 1995, 197; Martín et alii, 1999, 185). Esta cronología se sostuvo durante un tiempo para las de Niebla (Torres Balbás, 1960b, 431; Jiménez Martín, 1980, 23-24), aunque la arqueología las habría fechado en época almohade (Gómez et alii, 2001; Campos et alii, 2006, 367-369).

Del mismo modo, los almohades emplearon en al-Andalus, con independencia del directo que siguió utilizándose, tres tipos de accesos, puesto que, a diferencia del Magreb, no se documentan en al-Andalus ejemplares en los que primen por completo los valores estéticos y monumentales sobre los meramente defensivos (Jiménez Martín, 1995a, 176-177; Márquez y Gurriarán, 2008, 124-125)32.

1) Acceso en recodo abierto en una torre saliente de la muralla, con disposición muy similar a la Puerta Nueva o de las Pesas, como en las de Niebla (Pavón, 1999, 484 y 489), el Postigo de la Judería de Sevilla (Manzano, 1995, figura 3), la Puerta de Morón de Marchena (Bellido, 2010, 120-124) o la bāb al-Qabli del ribāt de Tit, en Marruecos (Basset y Terrasse, 1932, 358-361).

2) Acceso en recodo con un espacio a cielo abierto y una torre de flanqueo, evolución de la Puerta Monaita. Así se puede intuir en las del Puente, Osuna, Agua y Estepa del recinto de Écija, en la medida en que la documentación bajomedieval se refiere a ellas con el término "corraliza" (Hernández et alii, 1951, 213), y observarse en las de la alcazaba de Badajoz, denominadas del Capitel y del Alpéndiz (Torres Balbás, 1941a, 186-187; 1960b, 433), en la Porta do Templo de Elvas (Correia, 1996, 84; 2002, 360), en la Puerta del Arquillo o de la Pescadería de la localidad sevillana de Aznalcázar (Gavira, 2010) y las que daban acceso al antemuro que protegía el Postigo del Aceite (Quirós, 1999, 190191; Amores y Quirós, 1999, 44-45) y a la puerta documentada en la Portada de la Real Casa de la Moneda de Sevilla (Mora, 2010; 2013).

32 Así sucede en Marrakech y Rabāt, la una capital del imperio y la otra fundada por los Banū 'Abd al-Mu'min, donde se alzan la $b \bar{a} b$ Agnaou y la $b \bar{a} b$ er-Rouah y la de la qasba de los Udaya respectivamente, todas ellas construidas por Abū Yūsuf al-Mansūr en los últimos años del siglo VI/ XII (Marçais, 1926, 353-355; Terrasse, 1932, 294-298; Allain y Deverdun, 1957, 119-125; Cressier, 2005).
3) Acceso compuesto por la puerta de la muralla y la del antemuro, pudiendo ambas estar flanqueadas por torres unidas por puentes laterales, tipo del que conocemos tres ejemplares: la de la Medina o de Loulé de Silves (Correia, 1987, 508; Gomes, 2002, 333-334; 2006, 12 y 26), la del Repouso de Faro (Pavón, 1993, 75-77), ambas en el Algarve portugués, y la representación de la granadina de Elvira en la Batalla de Higueruela de El Escorial (Ibidem, 77-79). Además, se puede incluir aquí la puerta de la alcazaba exterior de Išbīlia, denominada desde principios del siglo XV de Jerez (Collantes de Terán, 1972, 49-50, documento 107). Esta se caracteriza, tal y como figura en el relieve del retablo mayor de la Catedral en el que se representa a la ciudad desde el sur, por un acceso flanqueado por dos torres y protegido por un antemuro en el que se abre un vano en línea recta con el de la muralla.

Las puertas de la Medina o de Loulé de Silves, la puerta del Repouso de Faro, la puerta de Elvira de Granada y la de la alcazaba exterior de Išbillia constituyen cuatro ejemplos a partir de los cuales es posible reconstruir la estructura de la puerta de la Macarena tras las reformas que introdujeron en ella los almohades (Jiménez Maqueda, 1996b). En todas ellas, encontramos referencias a antemuros que protegen la puerta, torres que pueden flanquear tanto el vano de la muralla como el del antemuro y puentes laterales, que enlazan torres y antemuro. Sin embargo, en las dos sevillanas se da la circunstancia de la ausencia de torres que flanqueasen el acceso del antemuro.

\subsection{OTROS ELEMENTOS.}

En la segunda fase del recinto sevillano están presentes otros elementos característicos de las fortificaciones de los Unitarios, tales como merlones rematados por albardillas piramidales (Valor, 1991; 2009, 53-54; Graciani, 2008, 54) $)^{33}$ y sendos rebajes curvos en la superficie de parapeto entre los merlones de la muralla (Collantes de Terán, 1977, 105; Valor, 1991), presentes también en el antemuro(Va-

33 Recientemente, el Dr. Amores ha afirmado en relación a los merlones con remate piramidal que su cronología almohade "creo que no esté tan claro", mientras que sugiere que correspondan a época medieval cristiana. Para sostener esta datación utiliza como argumento "los recrecidos en ladrillo sobre los prismas paralelepipédicos de tapial (sic) hasta el remate piramidal" de los escasos merlones que conserva la Torre del Oro, a los que califica de "anómalos" (Amores, 2014, 30-31). 
lor, 1991; Pozo, 2008, 167) y el Alcázar (Valor, 1991, 239).

Asimismo, un falso despiece a base de encintados de mortero de cal horizontales y verticales (Valor, 1991, 51-52; 2009, 198-199) 34 $^{34}$ verdugadas o marlotas de ladrillo como elemento decorativo en las torres de la cerca urbana (Valor, 1991; 2008a, 5253; 2009, 199-200; Graciani, 2008, 54; Pozo, 2008, 166) y en las de diversos recintos del Alcázar para los que se sostiene una datación almohade (Valor, 1991; Tabales, 2002c, 115-119); en la mayoría de los casos, se disponen a la altura de las almenas y a la del pavimento de la terraza o de la cámara (Valor, 1991).

Por el contrario, la muralla sevillana carece de fábricas complementarias en sus tapias, tales como zócalos de sillares o mampuestos ${ }^{35}$, así como aristas de sus torres resueltas mediante ladrillos, sillares o mampuestos ${ }^{36}$, recurso este que se generaliza en la segunda mitad del siglo VI/XII (Eslava, 1989, 55; Gurriarán, 2000, 113; Guarriarán y Sáez, 2002, 612613; Graciani y Tabales, 2008, 141-143; Graciani, $2009,117)^{37}$.

$34 \mathrm{Su}$ finalidad sería tectónica frente a los agentes erosivos, cuando discurren sobre la línea de las cabezas seccionadas de las agujas del encofrado o sobre una junta vertical de obra, decorativa y propagandística. En este sentido, hay quienes defienden que su utilización constituye uno de los componentes del lenguaje formal de las autoridades almohades en las fortificaciones andalusíes (Menéndez et alii, 1998; Azuar et alii, 1996; Azuar, 2004; 2005; Azuar y Ferreira, 2014; Márquez y Gurriarán, 2008). Sin embargo, hay quien ha sugerido que, en la ciudad de Granada, podría adelantarse a época zirí y retrasarse a la nazarí (García, 2014, 489).

35 Recalzando las estructuras de las tapias se documentan poderosos zócalos de sillares, como en Niebla (Pérez et alii, 1998, 348-351) o Carmona (Belén et alii, 1997, 656; Valor, 1998, 609-610), o mampuestos, como en Cáceres (Márquez y Gurriarán, 2003, 94), Silves (Gomes, 2006, 12, 16, 18 y 26), en la provincia de Ciudad Real en los castillos de Miraflores (Ruibal, 1994, 410; Molero et alii, 2014, 584-586), Salvatierra (Claros et alii, 2014) o Eznavexore (Ruibal, 1984, 441-442), en la de Badajoz los de Hornachos (Garrido, 1989, 154, 160 y 161), Montemolín (Ibidem, 251-253) y Reina (Ibidem, 273), en la de Jaén el de Giribaile (Armenteros et alii, 2010, 252) y el recinto de Alcaudete (Armenteros y Armenteros, 2006, 99, 100 y 103), Belalcázar (León, 2003, 186-189), los recintos onubenses de Almonaster la Real (Rivera y Romero, 2010, 2139-2140), Aroche (Rivera y Romero, 2006, 227) y Zufre (Romero y Rivera, 2009; Romero et alii, 2010) o el castillo sevillano de Aznalcóllar (Hunt, 1998, 386).

36 Con la excepción de sendas torres del Alcázar (Valor, 1991, 96-97; 1993, 385).

37 Se documenta, por sólo citar algunos ejemplos, en las

\subsection{LOS RECINTOS DEL ALCÁZAR.}

En relación a los diversos recintos con los que las autoridades almohades ampliaron el primitivo Alcázar 'abbādí (Tabales, 2002d; 2010a, 183 ss. y 236 ss.), el ejemplo más inmediato lo constituye el de Qurtuba. En ella, bajo la dominación almohade el ángulo sudoccidental de la medina, en el entorno del antiguo Alcázar omeya, fue ampliado con, al menos, dos nuevos recintos ${ }^{38}$, configurando así una extensa alcazaba (León et alii, 2008, 279; León y Blanco, 2010, 709-711; León, 2013, 345-347).

Por su parte, y reforzando aun más el estrecho paralelismo con el caso sevillano, la cabecera del puente romano fue fortificado con un recinto de planta de tendencia rectangular, erigido con muros de tabiya, flanqueado por torres en sus esquinas y a intervalos regulares en el centro de los lienzos y datado entre el último tercio del siglo VI/XII e inicios del VII/XIII (León et alii, 2008, 277-279; León y Blanco, 2010, 711-712; León, 2013, 347349).

En esta línea, la vecina Colina de los Quemados fue fortificada, a su vez, mediante un recinto del que se conservan una torre y varios lienzos de tabiya sobre un zócalo de mampostería y sillarejo, que también habría sido erigido entre finales del siglo VI/XII e inicios del VII/XIII (León et alii, 2008, 280; León y Blanco, 2010, 712; León, 2013, 349350). De este modo, desempeñaría un papel similar

dos torres almohades conservadas en el castillo sevillano de Alcalá de Guadaira (Domínguez, 2004, 75), en varias del recinto de Cáceres (Márquez y Gurriarán, 2003), en las de los castillos de Montemolín (Garrido, 1989, 251-253) y Reina (Ibidem, 273), en el castillo de Caracuel en la provincia de Ciudad Real (Ruibal, 1983, 405), en la provincia de Huelva en el castillo de Aroche (Rivera y Romero, 2006, 233) y los recintos de Tejada la Nueva (Campos y Vidal, 1999, 231-234; Vidal, 2007, 209-210) y Niebla (Pavón, 1996a, 19; Pérez et alii, 1998, 349; Gómez y Beltrán, 2006, 644 y 648; Campos et alii, 2006, 274), o en el castillo de Juromenha en el Alentejo portugués (Branco y Picard, 1992, 76).

38 Dichos recintos son conocidos por la historiografía local como Huerta del Alcázar y Castillo Viejo de la Judería. Este último configura un recinto de planta de tendencia rectangular, erigido con lienzos de tabiya, flanqueado en el centro de los mismos y en sus ángulos por torres cuadradas con cimentación y esquinas reforzadas con sillares y en el que destaca un acceso en recodo, aparejado en su totalidad en sillería a soga y tizón. Por otra parte, en su frente meridional ambos recintos incorporan un extenso tramo del antiguo malecón emiral que sostenía el arrecife, cuyo zócalo se reparó y regularizó con sillares y sobre el que se erigió un lienzo de hormigón de cal en el último cuarto del siglo VI/ XII (Murillo et alii, 2009-2010, 199-203). 
al del Hisn al-Faraŷ, en la localidad sevillana de San Juan de Aznalfarache ${ }^{39}$.

\section{CONCLUSIONES.}

Constituye una práctica habitual en el urbanismo almohade, la proliferación de recintos amurallados segregados de la medina ${ }^{40}$. La función de los mismos sería, fundamentalmente, la de aislar a las autoridades almohades, siempre recelosas, de la población local. A dicha función, cabría añadir la de albergar los numerosos contingentes que formaban un ejército de base tribal como el almohade. Sin embargo, en el caso sevillano lo excepcional es la multiplicación de los recintos, hasta el punto de que, si seguimos la hipótesis de Miguel Ángel Tabales, alcanzarían el número de nueve.

En cuanto al programa de puesta a punto y mejora de la cerca de Išbīlia en el primer cuarto del siglo VII/XIII, también tuvo lugar en otros puntos de al-Andalus. Por sólo citar algunos ejemplos, en Silves se conserva una lápida conmemorativa de la construcción de una torre en 624/1227 (Gomes, 2002, 334; 2006, 24 y 29), en Loja se ha sugerido una cronología similar para la Torre del Homenaje de la alcazaba (Márquez y Gurriarán, 2010), o en Marchena, donde las intervenciones arqueológicas (García y Díaz, 2001; Bellido, 2010, 141) y las características de sus tapiales (Graciani, 2009) fecharían la erección de su recinto también en el primer cuarto del siglo VII/XIII.

Con la excepción de las torres albarranas, los almohades dotaron al recinto sevillano de sus característicos dispositivos poliorcéticos, como torres poligonales, antemuro, corachas, cámaras abovedadas en las torres y accesos de gran complejidad, entre los que se pueden mencionar las puertas de la

39 Ibn 'I d̄ārī narra en el Bayān al-Mugrib cómo, en el año 589/1193, el califa Abū Yūsūf “(...) mandó planear una residencia en las afuera de Sevilla (...), que estuviese en la parte más alta del Aljarafe (...). Se levantó en el más breve tiempo el cuerpo de sus murallas y se señaló el emplazamiento de las casas y se acabó el alcázar grande con los salones que dominan Sevilla (...) lo llamó el castillo de Buenavista-Hisn alFaraŷ" (Huici, 1953, 176). La fábrica es de tapias de argamasa, mientras que las torres son rectangulares, próximas y de poco saliente, con varios puntos en los que todavía es visible un falso despiece a base de encintados de mortero de cal (Torres Balbás, 1960a, 121; Valor, 1995b).

40 Por sólo citar un ejemplo, en Maršāna, es decir la actual localidad sevillana de Marchena, se distinguen, además del recinto urbano, otros dos denominados por la historiografía local de la Alcazaba y del Parque (Bellido, 2010).
Macarena, Córdoba o Jerez. A estos dispositivos, se sumarían ciertos detalles constructivos propios de las fortificaciones de los Unitarios, como merlones rematados con albardillas piramidales, sendos rebajes curvos en la superficie de parapeto entre los merlones, un falso despiece de encintados de mortero de cal y verdugadas o marlotas de ladrillo.

Bibliografía

Abu, I. (2001), "Una puerta de madīna Garnāta: Bāb al-'Unaydar (Monaita)", Arqueología y Territorio Medieval, 8, 187-204.

Acién, M. (1995), "La fortificación en al-Andalus", La arquitectura del Islam occidental, Barcelona, 29-41.

Acién, M. y Rambla, J.A. (1991-1992), "Evolución de un hisn musulmán. La actuación arqueológica en el castillo de Monda”, Mainake, XIIIXIV, 277-294.

Aguilar, L. (1995), "Excavaciones de urgencia. C/ Muro. Año 1992. Jerez de la Frontera", Anuario Arqueológico de Andalucía/1992, III, 115-118.

(2000), "Nuevos datos sobre las murallas islámicas de Jerez de la Frontera", Revista de Historia de Jerez, 6, 99-113.

Alba, M. (2001), "Mérida, entre la Tardoantigüedad y el Islam: datos documentados en el Área Arqueológica de Morería”, La islamización de la Extremadura romana. Cuadernos Emeritenses, 17, 265-308.

Alba, M. de y Tabales, M.A. (2008), Memoria preliminar Intervención Arqueológica Preventiva en Calle Sol, $n^{\circ}$ 122. Análisis de la muralla islámica en el sector oriental de Sevilla, Documento interno de la Delegación Provincial en Sevilla de la Consejería de Cultura de la Junta de Andalucía.

Allain, C. y Deverdun, G. (1957), "Les portes anciennes de Marrakech”, Hespéris, XLIV, 85126.

Almagro, A. (2008), "La puerta califal del castillo de Gormaz", Arqueología de la Arquitectura, 5, 55-77.

Amores, F. (2007), "La intervención arqueológica", La Torre del Oro y Sevilla, Sevilla, 173-190.

(2010), “Análisis arqueológico de los paramentos y sondeos en las escalinatas exteriores de la Torre del Oro (Sevilla)", Anuario Arqueológico de Andalucia/2004.2, Sevilla, 848-861.

(2014), "Revisitar la Torre del Oro de Sevilla des- 
de la Arqueología”, Archivo Hispalense, 294296, 13-39.

Amores, F. y Quirós, C.A. (1997), "Primera intervención arqueológica en las antiguas Atarazanas de Sevilla", Anuario Arqueológico de Andalucía / 1993, III, 564-573.

(1999), "Las Atarazanas: el tiempo y los usos", Recuperando las Atarazanas. Un monumento para la cultura, Sevilla, 35-56.

Amores, F.; Rodríguez, J.M. y Campos, J.M. (1987), "Excavaciones en las murallas medievales de Sevilla. Sector coracha Torre del Oro", Anuario Arqueológico de Andalucía/1985, III, 343-345.

Arancibia, A. (2004), "Intervención arqueológica en la muralla musulmana de C/ Carretería $\mathrm{n}^{\text {os }}$ 62-64, Málaga”, Anuario Arqueológico de Andalucía/2001, III-2, 603-609.

Armas, D. de (1997), Livro das fortalezas, Facsimile do ms. 159 do Casa Forte de Arquivo Nacional da Torre de Tomo, Introduçao de Manuel da Silva Castelo Branco, Lisboa.

Azuar, R. (2004), "Técnicas constructivas y fortificación almohade en al-Andalus", Los almohades. Su patrimonio arquitectónico y arqueológico en el sur de al-Andalus, Sevilla, 57-74.

(2005), "Aspectos simbólicos de la arquitectura militar almohade. El falso despiece de sillería y las bóvedas de arcos entrecruzados", Los almohades: problemas y perspectivas. Volumen I, Madrid, 123-147.

Azuar, R. y Ferreira, I.C. (2014), "La fortificación del califato almohade", Las Navas de Tolosa 1212-2012. Miradas cruzadas, Jaén, 395420.

Azuar, R.; Lozano, F.J.; Llopis, T.M ${ }^{a}$ y Menéndez, J.L. (1996), "El falso despiece de sillería en las fortificaciones de tapial de época almohade en al-Andalus", Estudios de Historia y de Arqueología Medievales, XI, 245-278.

Al-Bakrī, A.U. (1913), Description de l'Afrique Septentrionale, Traducido por William Guckin de Slane, Argel.

Barrionuevo, F. y Aguilar, L. (2001), "Intervenciones arqueológicas de urgencia en Jerez de la Frontera, Cádiz c/Larga 61-63 y c/Francos 36", Anuario Arqueológico de Andalucía/1997, III, 68-72.

Basset, H. y Terrasse, H. (1932), Sanctuaires et forteresses almohades, París.

Belén, M.; Lineros, R.; Rodríguez, I.; Anglada, R. y Jiménez, A. (1997), "Excavaciones arqueológicas de urgencia en el solar $\mathrm{n}^{\mathrm{O}} 2$ de la calle Arellanos de Carmona (Sevilla)", Anuario Arqueológico de Andalucía / 1993, III, 655-666.

Bellido, T. (2010), Análisis arqueológico de las murallas de Marchena, Sevilla.

Bosch, J. (1984), Historia de Sevilla. La Sevilla islámica (712-1248), Sevilla.

Cabra, Mํㅡ. y Santiago, E.M ${ }^{\mathrm{a}}$ (1988), Iconografía de Sevilla 1400-1650, Madrid.

Campos, J.M.; Gómez, F. y Pérez, J.A. (2006), Ilipla-Niebla. Evolución urbana y ocupación del territorio, Huelva.

Campos, J.M. y Moreno, Mํㅜㄴ. (1988), "Excavaciones en la muralla medieval de Sevilla. El lienzo de la Macarena”, Archivo Hispalense, 218, 187206.

Campos, J.M. Moreno, MำT.; Vera, M. y Amores, F. (1987), "Excavaciones en el lienzo de muralla medieval de la Macarena", Anuario Arqueológico de Andalucía / 1985, III, 350-356.

Campos, J.M. y Vidal, N. (1999), "El urbanismo de las ciudades romanas del territorio onubense: el caso de Iptucci (Tejada la Nueva)”, II Congreso de Arqueología Peninsular. Arqueología romana y medieval. Tomo IV, Madrid, 229-236.

Caro, R. (1634), Antigüedades y Principado de la Ilustrissima Ciudad de Sevilla y Chorografia de su Convento Iuridico o Antigua Chancillería, Sevilla.

Carrasco, I. y Vera, E. (2001), "Intervención arqueológica de urgencia en un inmueble sito en calle Julio César número 14 esquina a Canalejas de Sevilla”, Anuario Arqueológico de Andalucía / 1998, III-2, 697-705.

(2003), "Intervención arqueológica de urgencia en c/ Bodegas 5 esquina a c/ Merinos. Écija (Sevilla)", Anuario Arqueológico de Andalucía/2000, III-2, 1288-1297.

Carriazo, J. de M. (1964-1965), "Inventario de hallazgos árabes", Noticiario Arqueológico Hispánico, VIII-IX, 361-362.

(1974-1975), "Una zanja en el suelo de Sevilla", Cuadernos de la Alhambra, 10-11, 91-97.

Carvalho, A.R.; Faria, J.C. y Ferreira, M.A. (2007), (Al-Qasr). Alcácer do Sal. Arqueologia e Historia de uma Madina do Garb al-Andalus (Séculos VIII-XIII), Alcácer do Sal.

Castillo, J.C.; Gutiérrez, L.M $M^{\mathfrak{a}}$ y Gutiérrez, $M^{\mathfrak{a}} \mathrm{V}$. (2010), "El asentamiento islámico de Giribaile (Jaén). De asentamiento de altura a castillo al- 
mohade", Cuadernos de Madinat al-Zahrā, 7, 239-262.

Castillo, J.L y Castillo, J.C. (2006), "Las defensas de Alcaudete (Jaén) en época almohade", $A r$ queología y Territorio Medieval, 13.1, 95-154.

Catarino, H. (1994a), "Os castelos de taipa do período muçulmano no sul de Portugal: o exemplo de Salir (Loulé)", Actas del I Congresso de Arqueologia Peninsula. Volumen 4, Porto, 335-344.

(1994b), "O Castelo de Paderne (Albufeira): resultados da primeira intervençâo arqueológica", $A r$ queologia Medieval, 3, 73-88.

(1997), "Castelos musulmanes do Algarve", Noventa séculos entre a serra e o mar, Lisboa, 449457.

(2001), "Castelos e territorio do Algarve em vésperas da Reconquista: a fortificaçao de Salir no alfoz de Loulé", Actas del V Congreso de Arqueología Medieval Española. Volumen 2, Valladolid, 693-705.

Choclán, C. y Castillo, J.C. (1991), "Excavación de urgencia en el solar C/ San Francisco, 3 y C/ Juan Robledo, 12 de Andújar", Anuario Arqueológico de Andalucía / 1989, III, 319-327.

Claros, C.; Segovia, A.; Aranda, A. y Martín, P. (2014), "El Castillo de Salvatierra: un enigma por desentrañar”, Las Navas de Tolosa 12122012. Miradas cruzadas, Jaén, 537-544.

Collado, A. Romero, C. y Carrasco, I. (2001), "Intervención arqueológica de urgencia en un solar sito en la calle Merinos no 38 de Écija. Sevilla”, Anuario Arqueológico de Andalucía / 1996, I, 657-663.

Collantes de Terán, F. (1968), Inventario de los Papeles del Mayordomazgo del siglo XIV, Sevilla.

(1972), Inventario de los Papeles del Mayordomazgo del siglo XV (1401-1416), Sevilla.

(1977), Contribución al estudio de la topografía sevillana en la antigüedad y en la edad media, Sevilla.

Cómez, R. (2000), "Notas sobre las Atarazanas de Sevilla", Archivo Hispalense, 254, 165-177.

(2008), "La Torre del Oro, revisitada", Archivo Hispalense, 276-278, 237-265.

(2012), "La puerta principal de la aljama almohade de Sevilla”, Archivo Hispalense, 288-290, 197218.

(2014), "Las Atarazanas de Sevilla. Una nueva lectura”, Archivo Hispalense, 294-296, 219-238.
Córdoba, R. (2004), "Fortificaciones almohades de la provincia de Córdoba”, Los almohades. Su patrimonio arquitectónico y arqueológico en el sur de al-Andalus, Sevilla, 123-129.

Correia, F.B. (1987), "Fortificaçoes musulmanas em Portugal: alguns apontamentos”, Arqueología Medieval Española: II Congreso. Tomo II: Comunicaciones, Madrid, 501-509.

(1996), "Espaços fortificados de época e influencia islâmica na margen direita do curso médio de Guadiana”, Bataliús: el reino taifa de Badajoz: estudios, Madrid, 77-88.

(2002), "O sistema defensivo da Elvas Islâmica", Mil Anos de Fortificaçoes na Península Ibérica e no Magreb (500-1500). Actas do Simposio Internacional sobre Castelos, Lisboa, 357-367.

Correia, F.B. y Picard, C. (1992), "Intervençao arqueológica no castelo de Juromenha. Primeiros resultados”, Arqueologia Medieval, 1, 71-89.

Cressier, P. (2005), "Les portes monumentales urbaines almohades: symboles et fonctions", Los Almohades: problemas y perspectivas. Volumen I, Madrid, 149-187.

Creswell, K.A.C. (1940), Early muslim architecture. Umayyads, Early 'Abbāsīds \& Tūlūnids. Part two, Oxford.

(1952), "Fortification in Islam before A.D. 1250", Proceeding of the British Academy, XXXVIII, 101-105.

(1958), "Bāb", Encyclopédie de l'Islam. Tomo I, Leiden-París, 853-855.

Delgado, C. (1991), "Recinto amurallado", Arquitecturas de Toledo. Del período romano al gótico, Toledo, 133-136.

(1999), "La estructura urbana de Toledo en época islámica”, Regreso a Tulaytula. Guía del Toledo islámico. Siglos VIII-XI, Toledo, 13-157.

Diehl, C. (1896), L'Afrique byzantine. Histoire de la domination byzantine en Afrique (533709), París.

Díes, E.; Pascual, J. y Roca, L. (2004), "Planificación y crecimiento urbano en la Valencia musulmana", La ciudad en el Occidente islámico medieval. Nuevas aportaciones de la arqueología y relectura de fuentes. Preactas. $1^{a} \mathrm{Se}$ sión: La medina andalusí, Granada.

Domínguez, E.L. (2001), "La remodelación urbana de Ishbilia a través de la historiografía almohade”, Anales de Arqueología Cordobesa, 12, 177-194. 
(2003), Teoría y práctica de la crítica historiográfica. Transformaciones socioproductivas $y$ procesos urbanos en Išbīlia-Sevilla (ss. XIXIII), Tesis doctoral de la Universidad de Sevilla. (2004), "Complejo fortificado de Alcalá de Guadaira. Historia y técnicas constructivas", Aparejadores, 68, 70-79.

(2008), "Sevilla y las fortificaciones fluviales del Guadalquivir", Actas $4^{\circ}$ Congreso Internacional sobre Fortificaciones: "Las fortificaciones y el mar", Alcalá de Guadaira, 231-250.

(2014), "Ishbilia entre dos mundos: arqueología de la Sevilla andalusí", Sevilla Arqueológica. La ciudad en época protohistórica, antigua y andalusí, Sevilla, 212-269.

Domínguez, E.L. y Amores, F. (2009), “Actividad arqueológica puntual toma de muestras y sondeo exterior en la Torre del Oro (Sevilla)", Anuario Arqueológico de Andalucía /2004.1, Sevilla, 3491-3512.

Eslava, J. (1986), "Las defensas de Arjona”, Boletín del Instituto de Estudios Giennenses, 125, 2591.

(1989), "Fortificaciones de tapial en al-Andalus y al-Magreb”, Castillos de España, 98, diciembre, 52-55.

Eslava, J. y Córcoles, J.V. (1980), "Las fortificaciones medievales de Andújar", Boletín del Instituto de Estudios Giennenses, 102, 9-40.

Falcón, T. (1979), "Planos urbanísticos del Corral de los Olmos y su entorno", Homenaje al Dr. Muro Orejón. Volumen 1, Sevilla, 245-256.

(1983), La torre del Oro, Sevilla.

Fernández, A. (1980), La fachada del Palacio de Comares. Situación, función y génesis. I, Granada.

Fernández, L.E (2004), "Informe preliminar de la intervención arqueológica de urgencia efectuada en la parcela número 20 de calle Carretería (Málaga)", Anuario Arqueológico de Andalucía/2001. III-2, 623-634.

Gamarra, F.E. y Camiña, N. (2006), "Excavación arqueológica de urgencia en Avenida de Roma y calle General Sanjurjo de Sevilla”, Anuario Arqueológico de Andalucía/2003, III-2, 488502.

García, J.A. (2014), "Entre ziríes y almohades. Las fortificaciones urbanas de Granada y su problemática arqueológica”, Las Navas de Tolosa 1212-2012. Miradas cruzadas, Jaén, 485497.
García, E. y Díaz, R. (2001), “Excavación arqueológica de urgencia en la calle Carrera $\mathrm{n}^{0} 35$ (Marchena, Sevilla)", Anuario Arqueológico de Andalucia / 1997, III, 613-619.

Garrido, M. (1989), Arquitectura militar de la Orden de Santiago en Extremadura, Mérida.

Gavira, M.A. (2010), "Intervención arqueológica de apoyo a la rehabilitación de la Puerta de La Pescadería (Aznalcázar, Sevilla). Primera fase de investigación”, Anuario Arqueológico de Andalucía/2004.2, Sevilla, 1062-1073.

Gilotte, S. (2008), "Émergence et déclin de la structure urbaine musulmane en Estrémadure centreorientale”, Castrum, 8. Le château et la ville. Espaces et réseaux (VI ${ }^{-}$-XIII ${ }^{e}$ siècle), 71-88.

(2009), “Al margen del poder. Aproximación arqueológica al medio rural extremeño (ss. VIIIXIII)”, Arqueología medieval. La transformació de la frontera medieval musulmana. II Curs Internacional d'Arqueologia Medieval, Lérida, 53-79.

Gomes, R.V. (2002), "Estructuras defensivas medievais de Silves", Mil Anos de Fortificaçoes na Península Ibérica e no Magreb (500-1500). Actas do Simpósio Internacional sobre Castelos, Lisboa, 325-336.

(2003), Silves (Xelb), uma cidade do Gharb AlAndalus: a Alcáçova. Trabalhos de Arqueologia, 35, Lisboa.

(2006), Silves (Xelb), uma cidade do Gharb AlAndalus: o núcleo urbano. Trabalhos de Arqueologia, 44, Lisboa.

(2009), "Silves y las fortificaciones del Gharb AlAndalus (siglos XII-XIII)", El castillo medieval en tiempos de Alfonso X el Sabio, Murcia, 78-98.

Gómez, F. y Beltrán, J.M. (2006), “Seguimiento arqueológico de apoyo a la restauración de las murallas de Niebla (Huelva): Fases de amurallamiento en el tramo Puerta de Sevilla-torre 26", Anuario Arqueológico de Andalucía/2003. III-1, 640-652.

Gómez, F.; Campos, J.M.; Guerrero, O. y Benabat, Y. (2001), "Arqueología urbana en Niebla. Actuación de apoyo a la restauración de la puerta de Sevilla”, Anuario Arqueológico de Andalucía / 1998, II, 112-120.

Gómez, M. (1951), "El arte árabe español hasta los almohades. Arte mozárabe”, Ars Hispaniae. Historia Universal del Arte Hispánico. Volumen III, Madrid. 
Gonçalves, M ${ }^{a} J$. (2009), "Silves islâmica: deambulando pelo Arrabalde Oriental”, Xelb, 9, 489524.

(2010), "Novas problemáticas relacionadas com a topografía da cidade islâmica de Silves”, $\mathrm{Ar}$ queologia Medieval, 11, 121-140.

González, J. (1951), Repartimiento de Sevilla, Madrid.

Graciani, A. (2008), "Propuesta de metodología científica para la caracterización constructiva de fábricas de tapial en los estudios previos. Su aplicación la muralla de Sevilla en el tramo del Jardín del Valle", IX Congreso Internacional de Rehabilitación del Patrimonio Arquitectónico y Edificación. Patrimonio Cultural e Innovación. Libro de Actas. Tomo I, Gran Canaria, 51-56.

(2008-2009), "Fábricas islámicas del mirador almohade de la Muralla de Marchena (Sevilla). Tramos de la Alcazaba y el parque", Laboratorio de Arte, 21, 13-35.

(2009), "La técnica del tapial en Andalucía Occidental”, Monografías Conjunto Monumental de la Alcazaba $n^{o}$ 2. Construir en al-Andalus, Almería, 111-140.

Graciani, A. y Tabales, M.A. (2008), "El tapial en el área sevillana. Avance cronotipológico estructural", Arqueología de la arquitectura, 5, 135158.

Granero, F. (1992), El Corral de los Olmos. Antiguos cabildos secular y eclesiástico de la ciudad. Sevilla. Sus orígenes, funciones, compilación de transformaciones y demolición, Sevilla.

Guerrero, J. (1953), "La puerta de Córdoba en la cerca de Sevilla", Al-Andalus, XVIII, 178-187.

Gurriarán, P. (2000), “Arquitectura y técnicas constructivas en al-Andalus durante la época almohade", Historia de las técnicas constructivas en España, Madrid, 109-121.

Gurriarán, P. y Sáez, A.J. (2002), "Tapial o fábricas encofradas en recintos urbanos andalusíes", II Congreso Internacional La ciudad en alAndalus y el Magreb, Granada, 561-625.

Herce, J.P. (1996), Informe de la intervención arqueológica de urgencia en $M^{a}$ Auxiliadora 39. Sevilla, Documento interno de la Delegación Provincial en Sevilla de la Consejería de Cultura de la Junta de Andalucía.

Herce, J.P. y Franco, C. (1997), Memoria científica de las intervenciones arqueológicas de urgencia en c/ Sol 128 y 130-134. Sevilla, Documento interno de la Delegación Provincial en Sevilla de la Consejería de Cultura de la Junta de Andalucía.

Hernández, J., Sancho, A. y Collantes de Terán, F. (1951), Catálogo Arqueológico y Artístico de la provincia de Sevilla, Tomo III, Sevilla.

Hernández, F. (1985), Madinnat al-Zahrā'. Arquitectura y decoración, Granada.

Hernández, J.C. (1993), "Noticias sobre el Arco de San Miguel y su derribo en el siglo XVIII", $L a$ boratorio de Arte, 6, 179-188.

Hita, J. y Villada, F. (2002), "De Septem Fratres a Sabta”, II Congreso Internacional La ciudad en al-Andalus y el Magreb, Granada, 483-499.

Huici, A. (1953), Colección de Crónicas Árabes de la Reconquista. Volumen II. Al-Bayān al-mugrib fi ijtisār ajbār muluk al-Andalus wa al-Magrib por Ibn 'Id ārī al-Marrākuūšīi. Los Almohades. Tomo I, Tetuán.

(1956), Historia política del imperio almohade, Tetuán.

Hunt, M. (1998), "El Castillo y la Torre de Aznalcóllar (Sevilla): dos edificios almohades", I Congreso Internacional Fortificaciones en al-Andalus, Algeciras, 379-388.

(2001), "Excavación arqueológica del Castillo de San Jorge (Triana, Sevilla)”, Anuario Arqueológico de Andalucía / 1998, III-2, 811-823.

(2008), Informe preliminar y memoria científica final. Intervención arqueológica preventiva "metro ligero-centro" (Metrocentro). Fase 1: Plaza Nueva-Prado de San Sebastián. Sevilla, Documento interno de la Delegación Provincial en Sevilla de la Consejería de Cultura de la Junta de Andalucía.

Hunt, M., Pozo, F.; López, P.; Vázquez, J.; Martínez, Mª̀D.; Méndez, E.; Gil, R.M ${ }^{a}$; Guijo, J.M.; Pecero, J.C.; Sánchez, O. y Casas, I. (2010), "Excavación arqueológica en la "Estación Puerta de Jerez", Fase I-A. Línea 1 del Metro de Sevilla (calle San Fernando, Sevilla)", Anuario Arqueológico de Andalucía /2006, 4481-4512.

Ibn Abī Zar' (1964), Rawd al-qirtās, Traducido y anotado por Ambrosio Huici, Valencia.

Ibn Sāhib al-Salāt (1969), Al-Mann bi-l-Imāma, Estudio preliminar, traducción e índices por Ambrosio Huici, Valencia.

Jiménez, P. y Sánchez, Mª J. (1997), “Un tramo de la muralla medieval de Murcia y el área urbana adyacente. El solar de calle Sagasta, esquina con 
calle Brujera”, Memorias de Arqueología, 12, 481-502.

Jiménez Maqueda, D. (1996a), "Algunas precisiones cronológicas acerca de las murallas de Sevilla”, Laboratorio de Arte, 9, 11-22.

(1996b), "La puerta de la Macarena. Un ejemplo de dispositivo poliorcético almohade en la muralla almorávide de Sevilla”, Norba-Arte, XVI, 7-17.

(1998a), "Algunas precisiones cronológicas sobre las murallas de Sevilla”, I Congreso Internacional Fortificaciones en al-Andalus, Algeciras, 333339.

(1998b), “¿Era la Bāb Ŷahwar la puerta de la Carne?”, Laboratorio de Arte, 11, 395-404.

(1998c), "Las murallas de Sevilla. Una aproximación historiográfica", Archivo Hispalense, 248, 9-31.

(1999a), Las puertas de Sevilla. Una aproximación arqueológica, Sevilla.

(1999b), "Las puertas medievales y postmedievales de la ciudad de Sevilla. Una aproximación histórico-arqueológica", Cuadernos de la Alhambra, 35, 149-159.

(2007), "Las murallas y las puertas", La Sevilla de Richard Ford 1830-1833, Sevilla, 167-180.

Jiménez Maqueda, D. y Pérez Quesada, P. (2012): "La muralla huérfana. A vueltas con el último recinto amurallado de madīnat Išbīlia", Romvla, 11, 273-347.

(2015), "El último recinto amurallado de madīnat Išbīlia. Estado de la cuestión y perspectivas de futuro", Onoba, 3, 51-77.

Jiménez Martín, A. (1980), Huelva monumental 1. Monumentos nacionales, Huelva.

(1981), “Análisis formal y desarrollo histórico de la Sevilla medieval”, La arquitectura de nuestra ciudad, Sevilla, 11-29.

(1995a), "Al-Andalus en época almohade”, La arquitectura del Islam Occidental, Barcelona, 165-180.

(1995b), "Mezquitas", El último siglo de la Sevilla islámica (1147-1248), Salamanca, 149-160.

(1996), "Cien edificios en cuatro jornadas", Arquitectura en al-Andalus. Documentos para el siglo XXI, Barcelona, 89-203.

(1998), "La proa de la balsa de piedra o la Puerta de Sevilla en la Edad Media”, Actas del I Congreso de Historia de Carmona. Edad Media. Congreso Conmemorativo del 750 Aniversario de la conquista de la ciudad de Carmona por Fernando III. 1247, Sevilla, 653-663.
(2000), "La explanada de Ibn Jaldún. Espacios civiles y religiosos de la Sevilla almohade", Sevilla 1248. Congreso Internacional Conmemorativo del 750 Aniversario de la Conquista de la ciudad de Sevilla por Fernando III, Rey de Castilla y León, Madrid, 43-71.

(2002), "Síntesis a modo de epílogo", Magna Hispalensis (I). Recuperación de la aljama almohade, Granada, 473-481.

(2005), "Mezquitas, castillos e iglesias. Notas sobre la arquitectura del siglo XIII en la Sierra de Huelva", La banda gallega: Conquista y fortificación de un espacio de frontera (siglo XIII-XVIII), Huelva, 121-202.

(2007a), "La ciudad almohade y los Caños de Carmona”, La Catedral en la ciudad (III). Los Caños y los difuntos. Primer tomo, Sevilla, 21-48.

(2007b), "Notas sobre la mezquita mayor de la Sevilla almohade", Artigrama, 22, 99-122.

Jiménez Sancho, A. (2002a), "Excavación arqueológica en dos pilares de la Catedral de Sevilla", Anuario Arqueológico de Andalucía/1999, III-2, 883-898.

(2002b), "Seguimiento arqueológico en la Puerta del Perdón de la Catedral de Sevilla", Anuario Arqueológico de Andalucía / 1999, III-2, 899908.

(2002c), "Excavación arqueológica en torno a dos pilares del Trascoro”, Magna Hispalensis (I). Recuperación de la aljama almohade, Granada, 297-337.

(2002d), "Seguimiento arqueológico en las gradas de la Puerta del Perdón”, Magna Hispalensis (I). Recuperación de la aljama almohade, Granada, 339-361.

(2002e), "Intervención arqueológica en el Patio de los Naranjos", Magna Hispalensis (I). Recuperación de la aljama almohade, Granada, 363-401.

(2003), "Excavación en el Patio de los Naranjos de la Catedral de Sevilla. Una mezquita amurallada”, Anuario Arqueológico de Andalucía/2000, III-2, 905-922.

León, A. (2003), Las fortalezas de Belalcázar (Córdoba): análisis arqueológico de su arquitectura (s. IX-XIX), Córdoba.

(2013), "Las fortificaciones de la Córdoba Almohade”, Fortificaçoes e Território na Península Ibérica e no Magreb (Séculos VI a XVI), Lisboa, 337-354. 
León, A. y Blanco, R. (2010), "La fitna y sus consecuencias. La revitalización urbana de Córdoba en época almohade", El Anfiteatro Romano de Córdoba y su entorno urbano. Análisis Arqueológico (ss. I-XIII d.C.). Monografías de Arqueología Cordobesa, 19. Volumen II, Córdoba, 699-726.

León, A.; León, E. y Murillo, J.F. (2008), “El Guadalquivir y las fortificaciones urbanas de Córdoba”, Actas $4^{\circ}$ Congreso Internacional sobre Fortificaciones: "Las fortificaciones y el mar”, Alcalá de Guadaira, 261-290.

Macías, S. (1993), "Moura na Baixa Idade Média. Elementos para um estudo histórico e arqueológico", Arqueologia Medieval, 2, 127-157.

Maia, M. (2006), “A Barbaca da Muralha de Tavira”, Xelb, 6, 41-50.

Manzano, R. (1995), "El Alcázar de Sevilla: los palacios almohades”, El último siglo de la Sevilla islámica (1147-1248), Salamanca, 101-124.

Marçais, G. (1926), Manuel d'art musulman: l'architecture: Tunisie, Algérie, Maroc, Espagne, Sicile. Tomo I, París.

Márquez, S. y Gurriarán, P. (2003), "La muralla almohade de Cáceres: aspectos constructivos, formales y funcionales", Arqueología y Territorio Medieval, 10.1, 57-118.

(2008), "Recursos formales y constructivos en la arquitectura militar almohade de al-Andalus", Arqueología de la Arquitectura, 5, 115-134.

(2010), "La Torre del Homenaje de la alcazaba de Loja (Granada)", Arqueología y Territorio Medieval, 17, 81-98.

(2012), "Tras las huellas de los almohades. Reflexiones sobre las últimas fortificaciones del Badajoz andalusí", Cuadernos de Arquitectura y Fortificación, 0, 55-76.

Martín, M.; Bleda, J. y Martín, J.M ${ }^{\mathfrak{a}}$ (1999), Inventario de arquitectura militar de la provincia de Granada (Siglos VIII-XVIII), Granada.

Martínez, Mª D. y Pozo, F. (2007), Memoria de Intervención Arqueológica Preventiva en redes de EMASESA de Plaza Nueva, Avda. de la Constitución, Plaza de Puerta de Jerez, Calle San Fernando, Avda. Carlos V y Calle Diego de Riaño. Sevilla 2007, Documento interno de la Delegación Provincial en Sevilla de la Consejería de Cultura de la Junta de Andalucía.

Martins, I.P. y Matos, J.L. (1971), "Muralhas de Loulé”, O Arqueólogo Português, série 3, volume 5, 227-247.
Medianero, J.Mª (1993), “Análisis y propuesta de integración urbana de los restos de la muralla de Sanlúcar la Mayor (Sevilla)", Arquitectura y ciudad II y III, Madrid, 260-269.

Melero, F. (2009), "La muralla de Málaga en la calle Álamos, 8", Anuario Arqueológico de Andalucia/2004, I, 2545-2552.

Menéndez, J.L.; Azuar, R.; Lozano, F.J. y Llopis, T.M ${ }^{a}$ (1998), "El falso despiece de sillería en las fortificaciones de tapial de época almohade en Al-Andalus", Actas del I Congreso Internacional de Castellología Ibérica, Palencia, 481511.

Menéndez, Mªㄴ. y Reyes, F. (1987a), "El Alcázar de Jerez de la Frontera”, Actas del I Congreso de Arqueología Medieval Española, Zarago$\mathrm{za}, 307-324$.

(1987b), "Estructuras defensivas de una ciudad almohade: Jerez de la Frontera", Arqueología Medieval Española: II Congreso. Tomo II: Comunicaciones, Madrid, 765-772.

Menéndez Pidal, R. (1906), Primera Crónica General. Estoria de España que mandó componer Alfonso el sabio y se continuaba bajo Sancho IV en 1299, Madrid.

Molero, J.; Arcos, Mª del C. y Molina, M. (2014), "Vigilar caminos, defender la frontera: la fortaleza almohade de Miraflores (Piedrabuena, Ciudad Real)", Las Navas de Tolosa 1212-2012. Miradas cruzadas, Jaén, 577-592.

Montes, C. y González, R. (1990), “Excavaciones arqueológicas en el casco urbano de Jerez. Año 1987. C/ Larga 21-25 y C/ Lancería 3-7”, Anuario Arqueológico de Andalucía / 1987, III, 99108.

Mora-Figueroa, L. de (1992), "La torre albarrana. Notas sobre su concepto, funcionalidad y difusión en la Europa occidental cristiana”, III Congreso de Arqueología Medieval Española. Actas. Tomo II: Comunicaciones, Oviedo, 52-62

(1994), Glosario de Arquitectura Defensiva Medieval, Cádiz.

Mora, G.M. (2010), “A vueltas con la muralla de Sevilla ¿Puertas o portillos? Resultados de la Arqueología aplicada a la portada de la Real Casa de la Moneda de Sevilla", V Congreso Internacional sobre Fortificaciones. Fortificación y ciudad, Sevilla, 67-76.

(2013), La Casa de la Moneda de Sevilla. Patrimonio inmueble y relación con el entorno, 
Tesis doctoral de la Universidad de Sevilla.

Moreno, Mำ "Investigaciones arqueológicas en las murallas medievales de Sevilla. Sector Jardines del Colegio del Valle", Anuario Arqueológico de Andalucía/1986, III, 285-290.

Morón, Mํ․ $\mathrm{F}$. (1998), "Las maquetas de la ciudad de Sevilla del año 1511”, La Catedral virtual. Curricula y resúmenes, Sevilla, 13-14.

Murillo, J.F.; Carrillo, J.R. y Ruiz, D. (1999), “Intervención arqueológica en el Paseo de la Victoria (Campaña 1993)", Anuario Arqueológico de Andalucia / 1994, III, 69-83.

Murillo, J.F.; Ruiz, D.; Carmona, S.; León, A.; Rodríguez, M르.; León, E. y Pizarro, G. (20092010), "Investigaciones arqueológicas en la muralla de la Huerta del Alcázar (Córdoba)", Anejos de Anales de Arqueología Cordobesa, 2, 183-230.

Orihuela, A. (1995), "Granada, capital del reino nazarí”, La arquitectura del Islam Occidental, Granada, 195-209.

Orihuela, A. y Rodríguez, A. (2004), "El urbanismo de la Granada andalusí: nuevas claves de su evolución", La ciudad en el Occidente islámico medieval. Nuevas aportaciones de la arqueología y relectura de fuentes. Preactas. $1^{a}$ Sesión: La medina andalusí, Granada.

Ortega, M. (2002), "Intervención arqueológica de urgencia en $\mathrm{M}^{\mathrm{a}}$ Auxiliadora $\mathrm{n}^{\circ} 37$ (Sevilla)”, Anuario Arqueológico de Andalucía/ 1999, III-2, 685-696.

Palomino, J. (1998), "Las murallas de la ciudad de Andújar y su pervivencia a través de las Actas Capitulares y el urbanismo", I Congreso Internacional Fortificaciones en al-Andalus, Algeciras, 341-345.

Pascual, J. y Martí, J. (2002), "El recinto fortificado de la Valencia musulmana", Mil Anos de Fortificaçoes na Península Ibérica e no $M a-$ greb (500-1500). Actas do Simpósio Internacional sobre Castelos, Lisboa, 291-309.

Paulo, L.C. (2009), "Medina Tavira e o Povoamento Islâmico do Sudeste Litoral Algarvio", Xelb, 9, 579-595.

Pavón, B. (1980), “Arte y arqueología hispanomusulmana. Torre octogonal de Niebla”, Al-Qantara, I, 411-412.

(1981), Jerez de la Frontera: ciudad medieval. Arte islámico y mudéjar, Madrid.

(1986), "Corachas hispanomusulmanas. Ensayo se- mántico arqueológico”, Al-Qantara, VII, 331381.

(1989), "Dos fortalezas islámicas un tanto olvidadas: Tarifa y Gafiq o Belalcázar”, Al-Qantara, X, 543-564.

(1990), Tratado de arquitectura hispanomusulmana I (aljibes, puentes, qanats, acueductos, jardines, desagües de ciudades y fortalezas, rutas hidráulicas, baños, corachas), Madrid.

(1992), Ciudades hispanomusulmanas, Madrid.

(1993), Ciudades y fortalezas lusomusulmanas. Crónica de viajes por el sur de Portugal, Madrid.

(1996a), Arquitectura islámica y mudéjar en Huelva y su provincia. Prototipos y espacios en la Andalucía Occidental, Huelva.

(1996b), España y Túnez: arte y arqueología islámica, Sevilla.

(1999), Tratado de arquitectura hispanomusulmana II. Ciudades y fortalezas, Madrid.

Peraza, L. de (1979), Historia de Sevilla, Transcripción, estudio y notas por Francisco Morales Padrón, Sevilla.

(1997), Historia de la ciudad de Sevilla, Edición, introducción e índices por Silvia María Pérez González, Sevilla.

Pérez, J.A.; Campos, J.M.; Rodrigo, J.Mª y Gómez, F. (1998), "Las murallas de madīna Labla (Niebla, Huelva)”, I Congreso Internacional Fortificaciones en al-Andalus, Algeciras, 347-352.

Pozo, F. (2003), "Control arqueológico de obras en calle María Auxiliadora n 37 (Sevilla)”, Anuario Arqueológico de Andalucía/2000, III-2, 1109-1117.

(2008), Memoria final de la Intervención Arqueológica Puntual en Murallas de la Macarena. Sector Puerta de Córdoba, Documento interno de la Delegación Provincial en Sevilla de la Consejería de Cultura de la Junta de Andalucía.

Pozo, F. y Somé, P. (2002), "Intervención arqueológica en solar de C/ Aguiar 5-7 (Sevilla)”, Anuario Arqueológico de Andalucía/1999, III-2, 790-806.

Pringle, D. (1981), The defence of byzantine Africa from Justinian to the arab conquest: an account of the military history and archaeology of the African provinces in the sixth and seventh centuries, Oxford.

Quirós, C.A. (1999), "Las Reales Atarazanas de Sevilla: preexistencias islámicas y fase fundacional 
del edificio", XXIV Congreso Nacional de Arqueología. Volumen 5, Murcia, 189-195.

Rambla, J.A. (2010), "La muralla islámica de Málaga. A.A.P. desarrollada en el edificio Carretería n 30, Málaga”, Anuario Arqueológico de Andalucía/2006, 3372-3380.

Rambla, J.A; Arancibia, A. y Salado, J.B. (2002), "Evolución del amurallamiento en la Málaga musulmana. Aportaciones de la arqueología de urgencia”, Mil Anos de Fortificaçoes na Península Ibérica e no Magreb (500-1500). Actas do Simpósio Internacional sobre Castelos, Lisboa, 813-818.

Rambla, J.A.; Íñiguez, Mª C. y Mayorga, J. (2003), "La construcción de la muralla musulmana de Málaga, un hito en la historia de la ciudad", Mainake, XXV, 133-176.

Ramírez, J. y Valor, M. (1999), "Las murallas de Sevilla. Apuntes historiográficos y arqueológicos", Qurtuba, 4, 167-179.

Ramírez, F.O. y Vargas, J.M. (1995), "Las murallas de Sevilla: intervenciones arqueológicas municipales”, El último siglo de la Sevilla islámica (1147-1248), Salamanca, 83-95.

Ravé, J.L. (1993), El alcázar y la muralla de Marchena, Marchena.

Retuerce, M. (1995), "La Meseta Islámica como tierra de frontera", Alarcos, 1195. El fiel de la balanza, Toledo, 81-98.

(1996), "Documentación arqueológica de una ciudad almohade de la Meseta”, Alarcos, 1995. Actas del Congreso Internacional conmemorativo del VIII centenario de la batalla de Alarcos, Cuenca, 211-222.

(1998a), "Arqueología y urbanismo de una villa medieval: Ágreda. Últimas intervenciones (1995-1998)", Qurtuba, 3, 240-242.

(1998b), "Calatrava la Vieja. Últimos descubrimientos sobre su arqueología y urbanismo", Qurtu$b a, 3,246-250$.

Retuerce, M. y Hervás, M.A. (2002), "Calatrava La Vieja. De medina a encomienda", Mil Anos de Fortificaçoes na Península Ibérica e no Magreb (500-1500). Actas do Simposio Internacional sobre Castelos, Lisboa, 311-317.

Retuerce, M. y Lozano, I. (1986), "Calatrava la Vieja: primeros resultados arqueológicos”, Actas del I Congreso de Arqueología Medieval Española, Zaragoza, 57-75.

Rivera, T. y Romero, E. (2006), “Análisis arqueológico del castillo de Aroche (Huelva)”, Anua- rio Arqueológico de Andalucía/2003, II, 225-235.

(2010), "Estudios arqueológicos en el paño norte del castillo de Almonaster la Real (Huelva)", Anuario Arqueológico de Andalucía/2006, 2138-2147.

Rodríguez, S. (1993), "Seguimiento de obras de infraestructura en Sevilla c/ Mateos Gago y Avda. de la Constitución”, Anuario Arqueológico de Andalucía /1991, III, 430-434.

Rodríguez, S. y Ramírez, F.O. (1997), "La Catedral de Sevilla y la antigua mezquita mayor almohade. Intervención arqueológica en la Puerta de San Cristóbal”, Anuario Arqueológico de Andalucía/1993, III, 557-563.

Rodríguez, S.; Ramírez, F.O. y Lafuente, P. (1994), "Excavación arqueológica en la Puerta de San Cristóbal de la Catedral de Sevilla", Actas del IV Congreso de Arqueología Medieval Española: sociedades en transición: actas. III: Comunicaciones, Alicante, 721-726.

Romero, E. y Rivera, T. (2009), "El registro arqueológico de la Torre de las Harinas (Zufre, Huelva)", Anuario Arqueológico de Andalucía/2004.1, 1868-1874.

Romero, E.; Rivera, T.; Monge, A.M. y Queiroz, P.F. (2010), "Torre de las Harinas (Zufre, Huelva). Estudio arqueológico de una fortificación medieval”, IV Encuentro de Arqueología del Suroeste Peninsular, Huelva, 1463-1470.

Romero, C. y Carrasco, I. (1997), "Excavación arqueológica en C/ Bodegas a C/ Ostos s/n. Écija. Sevilla”, Anuario Arqueológico de Andalucía/ 1993, III, 704-710.

Romo, A. (2001), "El tramo defensivo islámico de la intervención en c/ Cano y Cueto-Paseo Catalina de Ribera (Sevilla)", Anuario Arqueológico de Andalucía / 1996, I, 559-566.

Ruibal, A. (1983), "Estudio histórico-arqueológico del castillo de Caracuel", Al-Qantara, 4, 385410.

(1984), "Eznavexore o ¿Torres de Xoray? Vestigios islámicos en el primer enclave santiaguista de Ciudad Real”, Al-Qantara, 5, 429-450.

(1994), "Modificaciones arquitectónicas en una fortaleza islámica”, Actas del IV Congreso de Arqueología Medieval Española: sociedades en transición: actas. II: Comunicaciones, Alicante, 407-414.

Sáez, P., Ordóñez, S.; García, E. y García-Dils, S. (2002), "La cerca islámica de Écija (Sevilla)", 
Actas Congreso Internacional: Fortificaciones en el entorno del Bajo Guadalquivir, Alcalá de Guadaira, 255-263.

(2004), Écija. 1: La ciudad: carta arqueológica municipal, Sevilla.

Sáez, A.J. (2003), Tarifa, llave y guarda de toda España. Fortificación y urbanismo, Algeciras.

(2007), Las defensas de Gibraltar (siglos XIIXVIII), Málaga.

Sáez, A.J. y Torremocha, A. (2001), "Gibraltar almohade y meriní (Siglos XII-XIV)”, Actas de las VI Jornadas de Historia del Campo de Gibraltar, Almoraima, 25, 181-210.

Salem, A.A. (1979-1980), "Obras almohades en la muralla almorávide de Sevilla”, Revista del Instituto Egipcio de Estudios Islámicos en Madrid, XX, 173-181.

Sánchez, C. (2008), "Las murallas de Cáceres: excavaciones y novedades en la Ronda de Mira al Río”, Arqueología urbana en Cáceres. Investigaciones e intervenciones recientes en la ciudad de Cáceres y su entorno. Actas de las Jornadas de Arqueología del Museo de Cáceres, Cáceres, 233-246.

Sancho, A. (1975), Iconografía de Sevilla, Sevilla.

Sardá, D.; Vera, A; García, I.; León, M.; Sánchez, O. y Belascoain, F. (2003), "Intervención arqueológica de urgencia en la Avenida Menéndez Pelayo, núms. 5 y 7”, Anuario Arqueológico de Andalucia/2000, III-2, 1131-1142.

Seco de Lucena, L. (1968), "Acerca de la qawraŷa de la Alcazaba Vieja de Granada", Al-Andalus, XXXIII, 197-203.

Serrera, J.M., Oliver, A. y Portus, J. (1989), Iconografía de Sevilla 1650-1790, Madrid.

Suárez, J.M. (1989), "La Puerta Nueva o de San Fernando", Laboratorio de Arte, 2, 173-182.

Tabales, M.A. (2001a), "Las murallas del Alcázar de Sevilla”, Apuntes del Alcázar de Sevilla, 2, 7-35.

(2001b), "Intervención arqueológica en c/ Menéndez y Pelayo $\mathrm{n}^{\mathrm{o}} 19$. El antemuro de la muralla islámica en el sector oriental de Sevilla”, Anuario Arqueológico de Andalucía / 1996, I, 475-485.

(2002a), "Sondeos estratigráficos en el Alcázar de Sevilla. Campaña 1999”, Anuario Arqueológico de Andalucía / 1999, II, 212-233.

(2002b), "Contribución al estudio de la cerca islámica de Sevilla. Investigaciones en c/ Menéndez y Pelayo 43-45”, Anuario Arqueológico de
Andalucía / 1999, III-2, 716-734.

(2002c), El Alcázar de Sevilla. Primeros estudios sobre estratigrafía y evolución constructiva, Sevilla.

(2002d), "Cronología y distribución en los recintos islámicos del Alcázar de Sevilla”, Actas Congreso Internacional: Fortificaciones en el entorno del Bajo Guadalquivir, Alcalá de Guadaira, 265-275.

(2003a), "Investigaciones arqueológicas en el Patio de las Doncellas", Apuntes del Alcázar de Sevilla, 4, 7-25.

(2003b), "Investigaciones arqueológicas en el Alcázar de Sevilla. Campaña 2000", Anuario Arqueológico de Andalucía /2000, II, 45-69.

(2005a), "Primera fase de excavaciones en el Patio de las Doncellas del palacio de Pedro I. Alcázar de Sevilla", Anuario Arqueológico de Andalucía/2002, II, 51-76.

(2005b), "El Patio de las Doncellas del Palacio de Pedro I de Castilla. Génesis y Transformación", Apuntes del Alcázar de Sevilla, 6, 6-44.

(2010a), El Alcázar de Sevilla. Reflexiones sobre su origen y transformación durante la Edad Media. Memoria de Investigación Arqueológica 2000-2005, Sevilla.

(2010b), "Campañas arqueológicas 2002-2004 en el Alcázar de Sevilla. El Patio de las Doncellas", Anuario Arqueológico de Andalucía/2004, II. Sevilla, 1085-1126.

Tabales, M.A. y Jiménez Sancho, A. (2001), "Intervención arqueológica en el Pabellón de Oficinas de la Catedral de Sevilla (1997-1998)”, Anuario Arqueológico de Andalucía/1997, III, 429443.

(2002), "La Cilla de la Catedral y el sector meridional de la mezquita aljama de Sevilla”, Magna Hispalensis (I). Recuperación de la aljama almohade, Granada, 229-296.

Tabales, M.A.; Romo, A.S.; García, E. y Huarte, P. (2001), "Análisis arqueológico del sector exterior oriental de la Catedral de Sevilla", Anuario Arqueológico de Andalucía / 1996, I, 393-404.

(2002), "Investigaciones arqueológicas en la Acera de Levante de la Catedral de Sevilla”, Magna Hispalensis (I). Recuperación de la aljama almohade, Granada, 115-168.

Terrasse, H. (1932), L'Art hispano-mauresque des origines au XIII ${ }^{\text {eme }}$ siècle, París.

(1954), Les forteresses de l'Espagne musulmane, Madrid. 
Torremocha, A. (2004), "Fortificaciones almohades en la provincia de Cádiz”, Los almohades. Su patrimonio arquitectónico y arqueológico en el sur de al-Andalus, Sevilla, 103-122.

Torremocha, A. y Elboudjay, A. (2001), "Vestigios omeyas en las dos orillas del Estrecho", El esplendor de los Omeyas cordobeses. La civilización musulmana de Europa Occidental. Estudios, Granada, 294-301.

Torremocha, A.; Navarro, I. y Salado, J.B. (2002), "Estructuras defensivas de Algeciras islámica. Su análisis desde las fuentes escritas y el registro arqueológico”, II Congreso Internacional La ciudad en Al-Andalus y el Magreb, Granada, 452-482.

Torremocha, A. y Sáez, A.J. (1998), "Fortificaciones islámicas en la orilla norte del Estrecho", $I$ Congreso Internacional Fortificaciones en al-Andalus, Algeciras, 169-265.

Torres Balbás, L. (1934a), "Las torres del Oro y de la Plata en Sevilla", Archivo Español de Arte y Arqueología, 29, 89-104.

(1934b), "La Torre del Oro en Sevilla", Al-Andalus, II, 372-373.

(1941a), "La alcazaba almohade de Badajoz", AlAndalus, VI, 168-203.

(1941b), "El alminar de la iglesia de San José y otras construcciones de los ziríes granadinos”, $A l-A n$ dalus, VI, 422-446.

(1942a), "Gibraltar, llave y guarda de España”, $A l$ Andalus, VII, 168-216

(1942b), "Las torres albarranas", Al-Andalus, VII, 216-220.

(1944), "Excavaciones y obras en la Alcazaba de Málaga (1934-1943)", Al-Andalus, IX, 173-190.

(1946), “Atarazanas hispanomusulmanas", Al-Andalus, XI, 175-209.

(1948), "Cáceres y su cerca almohade", Al-Andalus, XIII, 446-472.

(1949), "Arte almohade, arte nazarí, arte mudéjar", Ars Hispaniae. Historia Universal del Arte Hispánico. Volumen IV, Madrid.

(1951), "Barbacanas", Al-Andalus, XVI, 454-480.

(1952), "Nuevas perspectivas sobre el arte de alAndalus bajo el dominio de los Almorávides", Al-Andalus, XVII, 402-433.

(1955), Artes almorávide y almohade, Madrid.

(1957), "Arte hispano-musulmán hasta la caída del califato de Córdoba", España Musulmana hasta la caída del califato de Córdoba (7111031 de J.C.). Instituciones y vida social e intelectual. Historia de España Menéndez Pidal Tomo V, Madrid, 331-788.

(1960a), "Aznalfarache=Hisn al-Faraŷ", Al-Andalus, XXV, 113-121.

(1960b), "Las puertas en recodo en la arquitectura militar hispanomusulmana", Al-Andalus, XXV, 419-441.

(1971), Ciudades hispanomusulmanas, Advertencia preliminar, introducción y conclusión por Henri Terrasse, Madrid.

Valdés, F. (1988), “Arqueología de al-Andalus de la conquista árabe a la extinción de las primeras taifas", El fallido intento de un estado hispánico musulmán (711-1085). Historia General de España y América. Tomo III, Madrid, 545-627.

(1991), "La fortificación islámica en Extremadura: resultados provisionales de los trabajos en las alcazabas de Mérida, Badajoz y Trujillo y en la cerca urbana de Cáceres”, Extremadura Arqueológica II. I Jornadas de Prehistoria y Arqueología en Extremadura (1986-1990), Mérida-Cáceres, 547-557.

(1998), "El urbanismo islámico de la Extemadura leonesa: cuatro pautas de desarrollo", Genèse de la ville islamique en al-Andalus et au Maghreb occidental, Madrid, 159-183.

(1999), "Las etapas constructivas de la alcazaba de Badajoz”, Bataliús II. Nuevos estudios sobre el reino taifa de Badajoz, Madrid, 149-168.

(2003), "La arquitectura militar en al-Andalus. Ensayo de sistematización”, Actas del IV Curso de Cultura Medieval Seminario: La Fortificación Medieval en la Península Ibérica, Aguilar de Campoo, 125-136.

Valencia, R. (1988), Sevilla musulmana hasta la caída del Califato. Contribución a su estudio, Madrid.

Vallejo, A. (2004), Madīnat al-Zahrā’. Guía oficial del conjunto arqueológico, Sevilla.

Valor, M. (1991), La arquitectura militar y palatina en la Sevilla musulmana, Sevilla.

(1993), "La arquitectura militar almohade en el conjunto de los Reales Alcázares de Sevilla", Arquitectura y ciudad II y III, Madrid, 382-388.

(1995a), "Las defensas urbanas y palatinas", El último siglo de la Sevilla islámica (1147-1248), Salamanca, 49-56.

(1995b), "Aznalfarache”, El último siglo de la Sevilla islámica (1147-1248), Salamanca, 145148. 
(1998), "Las defensas de Carmona", Actas del I Congreso de Historia de Carmona, Sevilla, 597-635.

(1999), "Las fortificaciones medievales de la bailía de Setefilla (Sevilla)", Actas del I Congreso de Castellología Ibérica, Aguilar de Campoo, 723-760.

(2002a), "De Hispalis a Isbiliya”, Edades de Sevilla. Hispalis, Isbiliya, Sevilla, Sevilla, 41-58.

(2002b), "Las fortificaciones de Sevilla", Mil Anos de Fortificaçoes na Península Ibérica e no Magreb (500-1500). Actas do Simpósio Internacional sobre Castelos, Lisboa, 319-324.

(2004), "Algunos ejemplos de construcciones defensivas almohades en la provincia de Sevilla", Los almohades. Su patrimonio arquitectónico y arqueológico en el sur de al-Andalus, Sevilla, 145-163.

(2008a), Sevilla almohade, Málaga.

(2008b), "Algunas ciudades del bajo Guadalquivir entre 1150 y 1260: Carmona, Écija, Niebla y Sevilla", Al-Andalus. País de Ciudades, Toledo, 133-175.

(2009), "La arquitectura defensiva desde 1147 a 1300: algunos ejemplos de Andalucía Occidental", El castillo medieval en tiempos de Alfonso X el Sabio, Murcia, 191-225.

(2014), "La muralla medieval de Sevilla. Otra interpretación”, Sevilla Arqueológica. La ciudad en época protohistórica, antigua y andalusí, Sevilla, 252-253.

Valor, M. y Casquete, N. (1991), "La Torre de la Plata de Sevilla. Memoria de la excavación arqueológica practicada en su cámara inferior", Anuario Arqueológico de Andalucía/1989, III, 432-436.

Valor, M. y Ramírez, J. (1999), "Sobre la cronología de las murallas", Sevilla almohade, Madrid, 27-39.

(2000), "Las defensas de Sevilla”, Sevilla. 1248. Congreso Internacional Conmemorativo del 750 Aniversario de la Conquista de la ciudad de Sevilla por Fernando III, Rey de Castilla y León, Madrid, 85-98.

Valor, M. y Tabales, M.A. (2002), "Las fortificaciones de Madina Isbiliya (Sevilla)", Cuadernos de Patrimonio Histórico 1. Ciudades amuralladas, Cuenca, 179-205.

(2005): "Urbanismo y arquitectura almohades en Sevilla. Caracteres y especificidad", Los almohades: problemas y perspectivas. Volumen I,
Madrid, 189-222.

Vidal, N. (2007), Análisis arqueologico de la romanización del territorio onubense, Huelva.

Viguera, Mํa J. (1998), "La ciudad almohade de Sevilla”, VIII Centenario de la Giralda (11981998), Córdoba, 15-30.

(1999), "Los almohades en Sevilla: 1147-1248", Sevilla almohade, Madrid, 19-23.

Zozaya, J. (1984), "Islamic fortifications in Spain: some aspects", Papers in Iberian Archaeology. BAR International Series, 193, 636-673.

(1992), "Las fortificaciones de al-Andalus", Al-Andalus. Las artes islámicas en España, Madrid, 63-73.

(2001), "Gormaz, portento de fortalezas", El esplendor de los Omeyas cordobeses. La civilización musulmana de Europa Occidental. Estudios, Granada, 112-117. 
